\title{
Amidoximes as Ligand Functionalities for Braided Polymeric Materials for the Recovery of Uranium from Seawater.
}

Mark A. Lashley, ${ }^{\S}$ Nada Mehio, ${ }^{\dagger}$ Joseph W. Nugent, ${ }^{\S}$ Erick Holguin, ${ }^{\S}$ Chi-Linh Do-Thanh, ${ }^{\dagger}$ Vyacheslav S. Bryantsev, ${ }^{\ddagger}$ Sheng Dai, ${ }^{\ddagger}$ and Robert D. Hancock. ${ }^{{ }^{*}}$

Department of Chemistry and Biochemistry, University of North Carolina Wilmington, Wilmington, North Carolina 28403,United States, Department of Chemistry, University of

Tennessee, Knoxville, TN 37996-1600, and Chemical Sciences Division, Oak Ridge National Laboratory, Oak Ridge, Tennessee 37831, United States.

${ }^{\S}$ University of North Carolina Wilmington

${ }^{\dagger}$ University of Tennessee

${ }^{\ddagger}$ Oak Ridge National Laboratory 


\section{Abstract.}

The formation constants of the $\mathrm{UO}_{2}{ }^{2+}$ cation with the amidoximate ligands bzam (benzamidoxime) and acetam (acetamidoxime) are reported. These are of interest in light of their proposed use as the functional groups of extractants for uranium in seawater. The formation constants of bzam with $\mathrm{UO}_{2}{ }^{2+}$ were measured by monitoring the absorbance of the $\pi \rightarrow \pi^{*}$ transitions in the UV spectrum of the bzam ligand in the presence of $1: 1 \mathrm{UO}_{2}{ }^{2+}$ as a function of pH. This yielded $\log \mathrm{K}_{1}=12.4$ for $\mathrm{UO}_{2}{ }^{2+}$ with bzam, and $\log \mathrm{K}=6.9$ for the equilibrium $\mathrm{UO}_{2}(\text { bzam })^{+}+\mathrm{OH}^{-}=\mathrm{UO}_{2}($ bzam $) \mathrm{OH}$ at $25{ }^{\circ} \mathrm{C}$ and ionic strength zero. The bzam complexes were also studied monitoring the fluorescence of the $\mathrm{UO}_{2}{ }^{2+}$ system. Analysis of the intense fluorescence that occurs in $5 \times 10^{-6} \mathrm{M} \mathrm{UO}_{2}{ }^{2+}$ solutions between $\mathrm{pH} 5$ and 9 suggested that this was due to the $\left[\left(\mathrm{UO}_{2}\right)_{3} \mathrm{O}(\mathrm{OH})_{3}\right]^{+}$trimer. Monomeric species such as $\mathrm{UO}_{2}{ }^{2+}$ and $\left[\mathrm{UO}_{2}(\mathrm{OH})_{4}\right]^{2-}$, and dimers such as $\left[\left(\mathrm{UO}_{2}\right)(\mathrm{OH})_{2}\right]^{2+}$, fluoresce only weakly. Titration of such solutions with bzam supported the above $\log \mathrm{K}$ values measured by absorbance, and with higher bzam concentrations yielded $\log \beta_{2}=22.3$. The acetam ligand does not have any absorbance, so that complexformation was monitored by fluorescence only. Formation constants measured by fluorescence may differ from those measured by other techniques such as absorbance. The agreement obtained between $\log \mathrm{K}$ values measured by absorbance and fluorescence for the bzam complex of $\mathrm{UO}_{2}{ }^{2+}$ supported the $\log \mathrm{K}$ values measured for the acetam complexes by florescence alone were reliable: $\log \mathrm{K}_{1}=13.6, \log \beta_{2}=23.7$, and $\log \mathrm{K} \mathrm{UO}_{2}(\text { acetam })^{+}+\mathrm{OH}^{-}=\mathrm{UO}_{2}($ acetam $) \mathrm{OH}=6.8$. The high $\log \mathrm{K}$ values found for the bzam and acetam complexes of $\mathrm{UO}_{2}{ }^{2+}$ were analyzed using DFT calculations. These $\log \mathrm{K}$ values are related to the ability of polymer-based extractants bearing bzam or acetam type functional groups to extract $\mathrm{UO}_{2}{ }^{2+}$ at a concentration of $1.3 \times 10^{-8} \mathrm{M}$ and in the competing $0.0025 \mathrm{M} \mathrm{CO}_{3}{ }^{2-}$ present in the oceans. 


\section{Introduction.}

There is presently considerable interest [1-6] in recovering uranium from the oceans. Uranium is present in seawater as the $\mathrm{UO}_{2}{ }^{2+}$ cation and various carbonato and hydroxy species at a total concentration of $3 \mathrm{ppb}\left(1.3 \times 10^{-8} \mathrm{M}\right)$ [7], which translates into a total of $4.5 \times 10^{9}$ tons of uranium, about 1000 times as much as is available from all known terrestrial ores. Current thinking is that a novel type of 'braided' ion exchange material should be employed that involves alkane chains that are a single carbon chain wide branching from a central braided thread, and extending out into the surrounding solution [5]. By using an electron beam and chemical processes, amidoxime groups can be attached to the chains [8]. The attachment of the amidoximes to the alkane chains projecting out into solution should overcome the problem of slow diffusion found with conventional ion exchange materials. The braided polymer with its amidoxime functional groups would form a net extending about one meter down into the ocean, and would be several $\mathrm{km}$ wide: the net would be placed, with suitable supports, across a current such as the Gulf Stream to provide a steady flow of water.

The idea of using amidoximes as functional groups for the extraction of $\mathrm{UO}_{2}{ }^{2+}$ dates back as far as 1954 [9]. Poly(acrylamidoximes) have been identified in exhaustive testing of some 200 different materials as the only polymer capable of extracting uranium at $\mathrm{pH} 8.3[10,11]$. There are currently no data available on the formation constants of simple amidoximes that would allow one to model the binding of $\mathrm{UO}_{2}{ }^{2+}$ by potential ion-exchange materials. Hirotsu et al. [12] have reported a potentiometric study of acetam, and its complexes with $\mathrm{UO}_{2}{ }^{2+}$ and $\mathrm{Cu}^{2+}$. They were unable to measure the very high first protonation constant of acetam, and so did not obtain any actual $\log \mathrm{K}_{1}$ values. They did show, however, that acetam based ion exchange materials could extract $\mathrm{UO}_{2}{ }^{2+}$ in the presence of concentrations of carbonate appropriate for seawater [13- 
15].The subject of this paper is the investigation by UV-visible and fluorescence spectroscopy of acetamidoxime (acetam), and benzamidoxime (bzam) (see Figure 1 for key to ligand abbreviations used here) as potential complexing ligands for the extraction of uranium. The interest will be how strongly these amidoximes complex $\mathrm{UO}_{2}{ }^{2+}$ at the typical $\mathrm{pH}$ range [16] for seawater of 7.5-8.5, with the uranyl present as the hydroxy and carbonato species formed under the conditions present in seawater [7]. These results can be compared with the recently reported $\log \mathrm{K}$ values of $\mathrm{UO}_{2}{ }^{2+}$ with the diamidoxime type ligands L1 and L2 [17].

The hydrolyzed species formed by $\mathrm{UO}_{2}{ }^{2+}$ in aqueous solution involve a variety of polymeric species in the mid-pH range [18-21]. The species distribution diagram as a function of $\mathrm{pH}$ for the $\mathrm{UO}_{2}{ }^{2+}$ cation at a concentration of $5 \times 10^{-6} \mathrm{M}$ is shown in Figure 2, calculated using the program HYSS [22] and critically selected constants at ionic strength zero and $25^{\circ} \mathrm{C}$ [18]. These constants appear to account well for the uranyl species present in solution over the $\mathrm{pH}$ range 2-14, and will be referred to here as the 'accepted model'. Of particular interest are the hydrolyzed species present in solution responsible for the intense fluorescence observed for solutions of uranyl salts between $\mathrm{pH} 5$ and 9 , since fluorescence is an important tool in this paper for following equilibria involving amidoximes. The fluorescence of $\mathrm{UO}_{2}{ }^{2+}$ in aqueous solution over a range of $\mathrm{pH}$ values is seen in Figure 3, which should be compared with the species present in Figure 2. Use of fluorescence to determine equilibrium constants has some problems, one of which is that fluorescence refers to excited state species $\left(\log \mathrm{K}^{*}\right)[23,24]$ so that formation constants measured in this way may be somewhat different from those measured by other techniques such as absorbance, which refer to the ground state species $(\log K)$. In this paper the $\log \mathrm{K}$ values for bzam are studied by both absorbance and fluorescence: the $\pi \rightarrow \pi^{*}$ transitions of the aromatic ring of bzam lead to intense absorbance bands in the UV that can be used 
conveniently to measure protonation constants, and monitor complex-formation reactions. The bzam ligand itself does not fluoresce, but some of the uranyl species present in solution fluoresce intensely [18] which can be used to monitor complex formation with both bzam and acetam. The $\log \mathrm{K}$ results obtained for the complexation of uranyl with bzam by both fluorescence and absorbance can then be used to assess the reliability of those obtained for acetam with uranyl by fluorescence only. It turned out that the $\log \mathrm{K}_{1}$ and $\log \beta_{2}$ values obtained for bzam and acetam with the uranyl ion were quite large, and in order to try to understand this, DFT calculations were carried out on these complexes to elucidate the factors that led to such high complex stability.

\section{Experimental:}

Materials: The ligands acetam and bzam were synthesized by literature methods $[25,26]$. $\mathrm{UO}_{2}\left(\mathrm{NO}_{3}\right)_{2} \cdot 6 \mathrm{H}_{2} \mathrm{O}$ (depleted) was obtained from Fisher, and used without further purification. All solutions were made up in deionized water (Milli-Q, Waters Corp.) of $>18 \mathrm{M} \Omega . \mathrm{cm}^{-1}$ resistivity. There was some evidence that acetam solutions at least were prone to hydrolysis over time, so that fresh stock solutions of both acetam and bzam were prepared immediately prior to use. UV-visible spectroscopy: UV-Visible spectra were recorded using a Varian 300 Cary 1E UVVisible Spectrophotometer controlled by Cary Win UV Scan Application version 02.00(5) software. A VWR sympHony ${ }^{\mathrm{TM}}$ SR60IC $\mathrm{pH}$ meter with a VWR sympHony ${ }^{\mathrm{TM}}$ gel epoxy semimicro combination $\mathrm{pH}$ electrode was used for all $\mathrm{pH}$ readings, which were made in the external titration cell, with $\mathrm{N}_{2}$ bubbled through the cell to exclude $\mathrm{CO}_{2}$. For lower concentrations of ligand or $\mathrm{UO}_{2}^{2+}$, a $10 \mathrm{~cm}$ cell (Starna) was used for recording spectra.

Fluorescence measurements: Emission spectra were determined on a Horiba Jobin Yvon Fluororlog-3 scanning fluorometer equipped with a $450 \mathrm{~W}$ Xe short arc lamp and a R928P detector. The instrument was configured to collect the signal in ratio mode with dark offset using 
$5 \mathrm{~nm}$ bandpasses on both the excitation and emission monochromators. The emission spectra were determined by measurements every $5 \mathrm{~nm}$ from 335 to $480 \mathrm{~nm}$ at $280 \mathrm{~nm}$ excitation wavelength. The fluorescence spectra of $\mathrm{UO}_{2}{ }^{2+}$ were recorded in water and used to analyze competition reactions with acetam. Titrations were carried out in an external titration cell, with $\mathrm{N}_{2}$ bubbled through the cell to exclude $\mathrm{O}_{2}$ and $\mathrm{CO}_{2}$.

NMR spectroscopy: ${ }^{1} \mathrm{H}$ NMR spectra were recorded on Bruker DRX $(400 \mathrm{MHz})$ or Bruker Avance $(600 \mathrm{MHz})$ spectrometers. Chemical shifts are recorded in ppm from DSS (4,4dimethyl-4-silapentane-1-sulfonic acid) with the solvent resonance as the internal standard (CDCls: $7.27 \mathrm{ppm})$.

Stability constant determination: The protonation constants of bzam were determined previously [27] by recording the variation of the intensity of the $\pi \rightarrow \pi^{*}$ transitions of the aromatic group of the $1.0 \times 10^{-4} \mathrm{M}$ ligand in water in the $250 \mathrm{~nm}$ to $350 \mathrm{~nm}$ region of the spectrum as a function of $\mathrm{pH}$. The protonation constants of acetam, which ligand is UV-silent, were determined by following the ${ }^{1} \mathrm{H}$ NMR signals of a $2.010^{-3} \mathrm{M}$ solution of acetam in $10 \%$ $\mathrm{D}_{2} \mathrm{O} / \mathrm{H}_{2} \mathrm{O}$ as a function of $\mathrm{pH}$. The protonation constants were fitted using the program Excel [28]. The program HySS [22] was used for modelling species distributions in solution, and calculating species distribution diagrams as a function of $\mathrm{pH}$. The protonation constants of bzam and acetam are seen in Table 1.

The determination of formation constants for binding of ligands such as bzam or acetam with $\mathrm{UO}_{2}{ }^{2+}$ may be problematic because of the presence of hydroxy-uranyl polymers [18-21] in the $\mathrm{pH}$ range where complex-formation may occur, i.e. $\mathrm{pH} 5-9$ in Figure 2. Any analysis of complex-formation must therefore include the formation constants for these polymers, and the 
accuracy with which $\log \mathrm{K}_{1}$ can be determined is limited by the accuracy with which the $\log \beta$ values are known for the formation of the hydroxy-uranyl polymers.

For determination of the formation constants of $\mathrm{UO}_{2}{ }^{2+}$ with bzam the $\pi \rightarrow \pi^{*}$ transitions were recorded as before [27], but this time with $1: 1 \mathrm{UO}_{2}{ }^{2+} / \mathrm{bzam}$ at $10^{-4} \mathrm{M}$ present. This titration gave the set of spectra seen in Figure 4. The variation of absorbance at five different wavelengths as a function of $\mathrm{pH}$ is seen in Figure 5. The solid lines fitted to the data points are theoretical curves fitted using the SOLVER module of Excel [28]. Analysis of this set of spectra shows that there are two $\mathrm{pH}$ dependent equilibria present in the $\mathrm{UO}_{2}{ }^{2+}$ bzam solutions. The equilibrium at $\mathrm{pH} 4.46$, best fitted as a two-proton equilibrium, is assigned to the formation of the $\mathrm{UO}_{2}{ }^{2+}$ bzam complex according to:

$$
\mathrm{UO}_{2}^{2+}+\text { bzamH }_{2}^{+} \leftrightarrows \mathrm{UO}_{2}(\text { bzam })^{+}+2 \mathrm{H}^{+}
$$

The species distribution diagram calculated using HYSS [22] in Figure 2 shows that the uranyl ion is present mainly as the $\mathrm{UO}_{2}{ }^{2+}$ cation at $\mathrm{pH} 4.46$, with only a modest concentration of hydroxy species present. This allows for a direct calculation of $\log \mathrm{K}_{1}$ for the $\mathrm{UO}_{2}{ }^{2+}$ complex of bzam as 12.4(1), including a small correction for the presence of $52 \%$ of the total uranyl species present at $\mathrm{pH} 4.46$ with $1 \times 10^{-4} \mathrm{M}$ total uranyl present as species other than $\mathrm{UO}_{2}{ }^{2+}$, mainly $\mathrm{UO}_{2}(\mathrm{OH})^{+}$, as calculated using HYSS and $\log \beta$ values for uranyl with hydroxide. [18-21]. The second $\mathrm{pH}$ dependent equilibrium apparent in Figure 5 at $\mathrm{pH} 7.06$ is assigned to the formation of a hydroxy complex of the uranyl bzam complex:

$$
\mathrm{UO}_{2}(\text { bzam })^{+}+\mathrm{OH}^{-} \leftrightarrows \mathrm{UO}_{2}(\text { bzam }) \mathrm{OH}
$$


This assignment gives rise to $\log \mathrm{K}(\mathrm{MLOH})=6.9$. The $\log \mathrm{K}$ values reported here for bzam and $\mathrm{UO}_{2}{ }^{2+}$ are seen in Table 1. In order to investigate this model of the equilibria involving the formation of the above uranyl bzam complexes, titrations of the uranyl bzam system were carried out, monitoring the fluorescence intensity. Titrations of the fluorescence intensity of $5 \times 10^{-6} \mathrm{M}$ uranyl solutions with no added bzam over the $\mathrm{pH}$ range 2-12 were carried out, which are shown in Figures 6 and 7. These were analyzed to determine which uranyl species (see Figure 8) in solution were responsible for the intense fluorescence seen in Figure 2. Further titrations were carried out of $5 \times 10^{-6} \mathrm{M}$ uranyl solutions with $5 \times 10^{-6} \mathrm{M}$ bzam, as well as $5 \times 10^{-5} \mathrm{M}$ bzam present, and analyzed for consistency with the absorbance based determinations of $\log \mathrm{K}$ for uranyl bzam species, as seen in Figure 9. A further titration of $5 \times 10^{-6} \mathrm{M}$ uranyl solutions with $0.05 \mathrm{M}$ bzam at $\mathrm{pH} 7.66$ was carried out (Figure 10), and similarly analyzed.

In the case of acetam, which has no peaks in the UV-visible region, the ${ }^{1} \mathrm{H}$ NMR shifts recorded in the presence of $1: 1 \mathrm{UO}_{2}{ }^{2+}$ plus acetam as a function of $\mathrm{pH}$ showed quite small shifts as compared to acetam alone. Analysis using HYSS [22] suggests that the very small shifts in the ${ }^{1} \mathrm{H}$ NMR spectra of the $2 \times 10^{-3} \mathrm{M}$ solutions used in the NMR titrations was because the uranyl was mostly precipitated out as colloidal $\mathrm{UO}_{2}(\mathrm{OH})_{2}(\mathrm{~s})$, and very little was actually present as bzam complexes. It was found that complexation with acetam quenched the intense fluorescence of $\mathrm{UO}_{2}{ }^{2+}$ at close to neutral $\mathrm{pH}$. The variation of fluorescence intensity with acetam concentration at $\mathrm{pH} 7.38$ was used to determine $\log \mathrm{K}_{1}$ for the $\mathrm{UO}_{2}{ }^{2+}$ acetam complex, as seen in Figure 11.

A further problem with the use of fluorescence to monitor complex-formation is that collisional quenching of fluorescence can produce decreases in intensity that resemble complex-formation, when complex-formation also produces a decrease in fluorescence intensity [24]. In order to 
exclude as far as possible the possibility that the decreases in fluorescence intensity of the uranyl ion produced here by titration with bzam and acetam actually reflected collisional quenching, the titrations were repeated using acetamide, which does not complex appreciably in solution with uranyl. It was found that such titrations produced no significant decrease in the fluorescence intensity of uranyl solutions. On the other hand, titration of uranyl solutions with the strongly complexing [18] carbonate or phosphate anions produced decreases in fluorescence intensity very similar to those produced by bzam and acetam.

Theoretical Calculations: Density functional theory (DFT) calculations were performed with the Gaussian 09 C.01 software [29]. We used the B3LYP [30] and M06 [31] density functionals with the standard Stuttgart small-core (SSC) 1997 relativistic effective core potential (RECP) [32], the associated contracted $[8 \mathrm{~s} / 7 \mathrm{p} / 6 \mathrm{~d} / 4 \mathrm{f}]$ basis set for uranium, and the $6-31++\mathrm{G}(\mathrm{d}, \mathrm{f})$ basis set

for the light atoms. Frequency calculations were performed at the B3LYP/SSC $/ 6-31+\mathrm{G}^{*}$ level to verify that geometries were minima and to compute zero point energies and thermal corrections using the rigid rotor-harmonic oscillator approximation. Using the gas phase geometries, implicit solvent corrections were obtained at the B3LYP/SSC/6-31+G(d) level using the IEF-PCM [33] and SMD [34] solvation models in Gaussian. We used a combination of the B3LYP functional with the IEF-PCM solvation model and the M06 functional with the SMD solvation model that were shown in our previous study [35] to provide the best overall performance in predicting the $\log \mathrm{K}_{1}$ values of uranyl complexes with negative oxygen donor ligands.

\section{Results and discussion:}

The Uranyl benzamidoxime system - absorbance: The protonation constants of bzam and acetam reported previously [27] are seen in Table 1 . The first protonation constants are very 
high, at 12.36 for bzam, and 13.21 for acetam, with the $\mathrm{pK}_{\mathrm{a}}$ being lower for bzam than acetam as expected from the electron-withdrawing nature of the aromatic ring of bzam. The second protonation constant of acetam of 5.78 determined by us [27] is in reasonable agreement with that determined potentiometrically by Hirotsu et al.[12] of 5.90, determined at ionic strength 0.1 , rather than 0.0 as is used here. The titration of $10^{-4} \mathrm{M}$ bzam in the presence of $10^{-4} \mathrm{M} \mathrm{UO}_{2}\left(\mathrm{NO}_{3}\right)_{2}$ over the $\mathrm{pH}$ range 2.08-7.86 is seen in Figure 4. The spectral changes around $\mathrm{pH} 4.44$ appear to correspond to the complex-formation equilibrium where the bzam complex is formed from the $\mathrm{UO}_{2}{ }^{2+}$ cation as seen in equation [1] above. This leads to quite a high $\log \mathrm{K}_{1}$ for bzam with $\mathrm{UO}_{2}{ }^{2+}$ of 12.4. This can be compared with $\log \mathrm{K}$ values [36] for other bidentate strongly basic

Scheme 1. Diagrammatic representation of the bis-complexes formed by uranyl with mono-amidoximes, showing the $\eta^{2}$ mode of coordination of the amidoxime groups with uranyl that has been observed crystallographically [38].

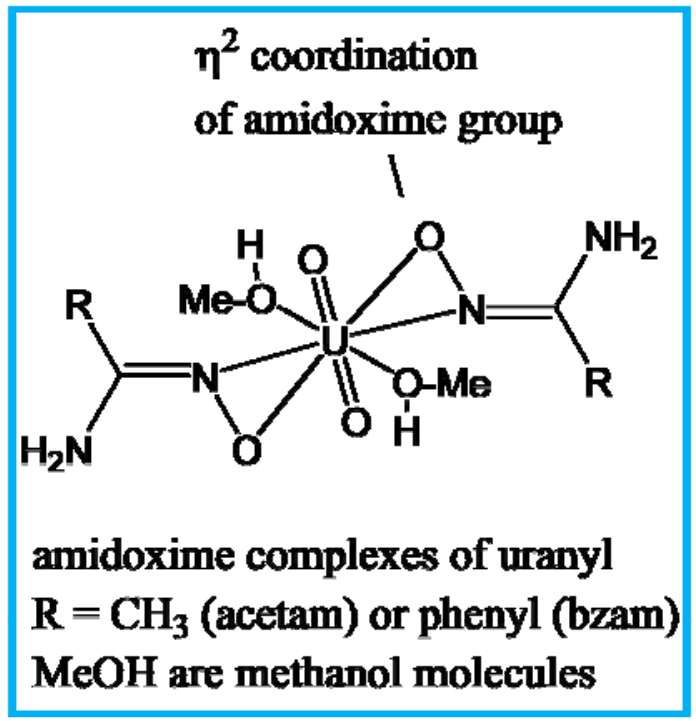
negative oxygen-donor ligands such as salicylate $\left(\mathrm{pK}_{\mathrm{a}}=13.7, \log \mathrm{K}_{1}\left(\mathrm{UO}_{2}\right)=13.1\right)$.

A search of the CSD [37] shows that amidoximes form complexes with uranyl that have the $\mathrm{N}$ and $\mathrm{O}$ forming three membered rings in a $\eta^{2}$ fashion as seen in scheme 1 [ 38-40]. The oxime group itself, as opposed to the amidoxime group discussed here, also consistently yields $\eta^{2}$ coordinated N-O groups with the uranyl cation, with 17 such structures in the CSD [37]. There are no other ligands structurally similar to amidoximes with which to compare the $\log \mathrm{K}_{1}$ value of bzam

(and acetam). The $\log \mathrm{K}_{1}$ of 12.4 for bzam with uranyl determined here suggests that the $\mathrm{N}$ donor portion of the $\eta^{2}$ bound amidoxime group lends considerable stability to the complex formed 
with $\mathrm{UO}_{2}{ }^{2+}$ : in comparison $\log \mathrm{K}_{1}$ for $\mathrm{UO}_{2}{ }^{2+}$ is only 5.9 with phenol, with bonding through a single negative $\mathrm{O}$ donor only [36]. The idea that the $\eta^{2}$ mode of coordination considerably stabilizes acetamidoxime complexes with $\mathrm{UO}_{2}{ }^{2+}$ is supported by DFT calculations that suggest [38] that coordination of acetam to the $\mathrm{UO}_{2}{ }^{2+}$ cation via the $\eta^{2}$ mode stabilizes the complex by some $10 \mathrm{kcal} . \mathrm{mol}^{-1}$ compared to coordination via a negative $\mathrm{O}$ donor only. The same calculations also show that the $\eta^{2}$ mode of coordination is considerably more stable than five membered chelate rings that are formed involving the $\mathrm{O}$ donor of acetam, plus a deprotonated $-\mathrm{NH}_{2}$ (amide) group of the ligand [38]. The structures of uranyl amidoxime complexes [38-40] show short U-O bonds averaging $2.38 \pm 0.05 \AA$ and U-N bonds averaging $2.41 \pm 0.06 \AA$ involving the donor atoms of the $\eta^{2}$ coordinated oxime group. These can be compared with the more typical U-O bonds of $2.46 \pm 0.02 \AA$ for coordinated water or methanol molecules in the same structures. The short U-O and U-N bonds, involving the coordinated $\eta^{2}$ oxime group are in line with the high thermodynamic stability of uranyl complexes involving coordinated amidoximes reported here. The U-N bonds are of particular interest, as these are considerably shorter than U-N bonds to other ligands involving $\mathrm{sp}^{2}$ hybridized N. A search of the CSD [37] yields 294 such structures, with $\mathrm{U}-\mathrm{N}$ bonds involving $\mathrm{N}$ donors from $\mathrm{C}=\mathrm{N}$ groups averaging $2.53 \pm 0.10 \AA$.

Fluorescence of Uranyl species in solution: It is helpful to know which species in solution cause the intense fluorescence of the uranyl ion if such fluorescence is to be used to calculate log $\mathrm{K}_{1}$ for bzam or acetam with $\mathrm{UO}_{2}{ }^{2+}$. A considerable amount of work has established that the $\mathrm{UO}_{2}{ }^{2+}(a q)$ cation itself in aqueous solution absorbs light in the visible region only weakly, and also fluoresces only weakly [41-47]. A complex such as the hydroxy bridged dimer $\left[\left(\mathrm{UO}_{2}\right)_{2}(\mathrm{OH})_{2}\right]^{2+}$ absorbs and fluoresces at a low to intermediate level, while the trimer $\left[\left(\mathrm{UO}_{2}\right)_{3} \mathrm{O}(\mathrm{OH})_{3}\right]^{+}$absorbs and fluoresces very strongly. The inclusion of the solubility product 
$\left(\log \mathrm{K}_{\mathrm{so}}\right)$ for $\mathrm{UO}_{2}(\mathrm{OH})_{2}(s)$ of -22.0 present in Smith and Martell [36] in the calculations using HYSS [22] suggests that precipitates of this solid will form in $5 \times 10^{-5} \mathrm{M}$ total uranyl solutions between $\mathrm{pH} 7.5$ and 9.7, although the formation of such precipitates is very slow [21]. No indication of hydroxide precipitation was observed here during titrations even in $10^{-4} \mathrm{M} \mathrm{UO}_{2}{ }^{2+}$ solutions. Our calculations indicate that in $5 \times 10^{-6} \mathrm{M}$ total uranyl solutions, no hydroxide precipitate will form at any $\mathrm{pH}$. The concentrations of the uranyl hydroxy species present in a 5 x $10^{-6} \mathrm{M}$ solution of $\mathrm{UO}_{2}{ }^{2+}$, where no precipitates of $\mathrm{UO}_{2}(\mathrm{OH})_{2}(\mathrm{~s})$ should be expected, were calculated for each $\mathrm{pH}$ titration point in Figure 7 using HYSS [22] and selected $\log \beta$ values for the hydroxo complexes of uranyl [18] and entered into an EXCEL file [28], along with the value of the fluorescence intensity at each $\mathrm{pH}$. The fluorescence intensities over the whole $\mathrm{pH}$ range in Figure 7 were thus modeled as $\Sigma\left[\left(\mathrm{UO}_{2}\right)_{\mathrm{x}} \mathrm{O}_{y}(\mathrm{OH})_{z}\right] \mathrm{I}\left(\mathrm{UO}_{2}\right)_{\mathrm{x}} \mathrm{O}_{y}(\mathrm{OH})_{z}$ where $\left(\mathrm{UO}_{2}\right)_{\mathrm{x}} \mathrm{O}_{y}(\mathrm{OH})_{z}$ are all the uranyl species present in solution (charges on species ignored), and $\left[\left(\mathrm{UO}_{2}\right)_{\mathrm{X}} \mathrm{O}_{y}(\mathrm{OH})_{z}\right]$ and $\mathrm{I}\left(\mathrm{UO}_{2}\right)_{x} \mathrm{O}_{y}(\mathrm{OH})_{z}$ are respectively the molarities and the contributions to the total fluorescence intensity at each $\mathrm{pH}$ point of each species. The SOLVER module of EXCEL [28] was used to adjust all the $\mathrm{I}\left(\mathrm{UO}_{2}\right)_{\mathrm{x}} \mathrm{O}_{y}(\mathrm{OH})_{z}$ values to minimize the differences between the observed and calculated fluorescences at each point over the whole $\mathrm{pH}$ range of the titration in Figure 7. To attempt to avoid false minima for the analysis, a great variety of starting fluorescence intensities for each species present in the minimization was tried. It was found that false minima could be produced with some starting sets of trial fluorescence intensities. What appeared to be a robust global minimum was obtained that showed that all monomeric uranyl species fluoresced only weakly, as was also true for dimeric species such as $\left[\left(\mathrm{UO}_{2}\right)_{2}(\mathrm{OH})_{2}\right]^{2+}$. Only the trimeric and tetrameric polyhydroxy species ever showed intense fluorescences in the analysis, and in particular, the fluorescence was dominated by the trimeric $\left[\left(\mathrm{UO}_{2}\right)_{3} \mathrm{O}(\mathrm{OH})_{3}\right]^{+}$species. This 
produced the calculated curve in Figure 7, based on the critically selected $\log \beta\left(\left(\mathrm{UO}_{2}\right)_{\mathrm{x}} \mathrm{O}_{y}(\mathrm{OH})_{z}\right)$ formation constants in reference [18]. This fit of calculated and observed fluorescence suggested that the intense fluorescence observed between $\mathrm{pH} 5$ and 9 in Figure 7 is primarily due to the trimeric $\left[\left(\mathrm{UO}_{2}\right)_{3} \mathrm{O}(\mathrm{OH})_{3}\right]^{+}$species, with lesser contributions from the $\left[\left(\mathrm{UO}_{2}\right)_{3} \mathrm{O}(\mathrm{OH})_{5}\right]^{-}$and $\left[\left(\mathrm{UO}_{2}\right)_{4} \mathrm{O}(\mathrm{OH})_{5}\right]^{+}$species. The latter contributions are smaller because these species are present in much smaller concentrations. Contributions to the fluorescence from other species present were more than two orders of magnitude less than the contributions of these three species. The common feature present in the strongly fluorescing species is a structural motif where an oxide ion is surrounded by three uranyl groups. The structures of some polymeric uranyl species as suggested by crystal structures available from Åberg [48] and the CSD [37] are shown diagrammatically in Figure 8. One sees at a) in Figure 8 the dimeric di-hydroxy bridged uranyl species $\left[\left(\mathrm{UO}_{2}\right)_{2}(\mathrm{OH})_{2}\left(\mathrm{H}_{2} \mathrm{O}\right)_{6}\right]^{2+}[48,49,50]$, which is shown to be present close to $\mathrm{pH} 5$ in Figure 2. Analysis of the origin of fluorescence intensity suggests that this species fluoresces only weakly. Structure b) in Figure 8 is that reported by Åberg [48] for the trimeric $\left[\left(\mathrm{UO}_{2}\right)_{3} \mathrm{O}(\mathrm{OH})_{3}\right]^{+}$ species, which is dominant between $\mathrm{pH}$ 5-9 in Figure 2. This is an important structural motif for uranyl complexes that is present in some 54 structures reported in the CSD [37], where a central oxide ion is surrounded by three coordinating uranyl groups. A variety of structures of this type are known where waters or hydroxides in structure b) are replaced with, for example, nitrates or carboxylates [51]. The same motif is present in structure c) in Figure 8, except that in this case four uranyl groups surround two oxide ions, each oxide being surrounded by three uranyl groups. This structure is based on one reported [52], which resembles the structure for $\left[\left(\mathrm{UO}_{2}\right)_{4} \mathrm{O}_{2}(\mathrm{OH})_{3}\right]^{+}$ shown, except that two coordinated water molecules are replaced by neutral oxygen donors from complex amide molecules. Again, the motif of two oxides surrounded by four uranyl groups, as 
shown in structure c) occurs quite frequently in the CSD, with examples where coordinated waters or bridging hydroxides are replaced by chlorides or $\mathrm{N}$ bonding thiocyanates $[53,54]$. It seems highly likely that the structures of the $\left[\left(\mathrm{UO}_{2}\right)_{3} \mathrm{O}(\mathrm{OH})_{3}\right]^{+},\left[\left(\mathrm{UO}_{2}\right)_{3} \mathrm{O}(\mathrm{OH})_{5}\right]^{-}$and $\left[\left(\mathrm{UO}_{2}\right)_{4} \mathrm{O}^{2}(\mathrm{OH})_{3}\right]^{+}$species are as shown at b) and c) in Figure 8. It may be that the strongly fluorescing species in Figure 7 are those that have the motif of one or two oxides each surrounded by three uranyl groups.

If one considers factors that might control the fluorescence intensity of uranyl species in solution [55], it appears that these might be: 1) deactivation via O-H stretching modes of coordinated water, 2) intra-molecular energy transfer to vibrations of solvent water, and 3) actual photochemical formation of free radicals, bearing in mind that the photo-excited state of the uranyl ion is a powerful oxidant, with an oxidation potential of some $2.6 \mathrm{~V}$. It seems reasonable to suggest that the oxide-centered uranyl polymers in solution may fluoresce so strongly because of a reduction in factors 1) and 2) above that reduce fluorescence intensity, which reduction in quenching of fluorescence is caused by the presence of the central oxide groups. These oxide groups should greatly cut down on the presence of fluorescence-quenching $\mathrm{O}-\mathrm{H}$ groups. A further factor may be that the absorbance intensities of polymeric uranyl species in solution are much higher than for monomeric species [41], which would lead to higher fluorescence intensities in the polymeric species.

The curve of fluorescence intensity vs $\mathrm{pH}$ in Figure 7 when calculated using only the critically selected $\log \beta$ values for uranyl hydroxy species in reference [18] does not account for the 'tail' of fluorescence intensity between $\mathrm{pH} 9$ and 11. Incorporation of the species $\left[\left(\mathrm{UO}_{2}\right)_{3} \mathrm{O}_{2}(\mathrm{OH})_{4}\right]$ with a $\log \beta$ in the vicinity of 70 , which was used to generate the theoretical curve in Figure 7, allows one to generate the extra fluorescence observed between $\mathrm{pH} 9$ and 11 in 
Figure 7. This species has been detected by Raman spectroscopy in small concentrations in solutions of uranyl ions [56], along with polymeric species such as $\left[\left(\mathrm{UO}_{2}\right)_{3}(\mathrm{OH})_{10}\right]^{4-}$, and $\left[\left(\mathrm{UO}_{2}\right)_{3}(\mathrm{OH})_{11}\right]^{5-}$, in addition to the usual species present in the accepted model [18]. The two small peaks of fluorescence intensity as a function of $\mathrm{pH}$ present on top of the large peak of fluorescence intensity are highly reproducible in the several runs of the titration in Figure 7 that were carried out. It is quite possible that these could be accounted for by further polymeric species not accounted for in the accepted model [18]. Examination of the CSD reveals even higher polymers of the uranyl system, such as a hexamer involving azides [57], but also having the motif of oxides surrounded by uranyl groups, and it may be small concentrations of similar species containing hydroxides that cause the above small amounts of extra fluorescence intensity. It should be realized that all these extra species compared to the accepted model [18] would be present at only a few percent of the total uranyl present in solution, and so should not much affect the accepted model [18].

The Uranyl benzamidoxime system - fluorescence: The absorbance studies of the uranylbenzam system yielded $\log \mathrm{K}_{1}=12.4$ and $\log \beta(\mathrm{MLOH})=19.3$. The aim was to see how well these constants, used unadjusted, could account for the fluorescence behavior of uranyl bzam complexes. The fluorescence titration seen in Figure 7 was repeated with 1:1 bzam:uranyl and 10:1 bzam:uranyl present, yielding the plots of fluorescence intensity versus $\mathrm{pH}$ seen in Figure 9. It is seen that the fluorescence intensity due to the uranyl ion is progressively decreased as the concentration of bzam is increased. The solid lines in Figure 9 are generated using the same fluorescence intensities for each uranyl species as generated in the analysis in Figure 7. New species distribution diagrams for the 1:1 bzam:uranyl titration, and the 10:1 bzam:uranyl titration were generated using HYSS [22], based on the above log K values obtained for the bzam-uranyl 
system from absorbance titrations. The fluorescence intensities for each uranyl species obtained from Figure 7 were used to calculate fluorescence intensities as a function of $\mathrm{pH}$ that were superimposed on Figure 9. It was found that this reproduced quite satisfactorily the curve of fluorescence intensity versus $\mathrm{pH}$ for the 1:1 bzam-uranyl system, except that use of Solver [28] to adjust the contributions to the overall fluorescence of the fluorescence intensities of uranyl bzam-containing species suggested that these had moderately intense fluorescence, being more than an order of magnitude less than for the polymeric hydroxo uranyl species. The fluorescences of the uranyl bzam complexes led to calculation of only a small contribution to the overall fluorescence, and so even if these were ignored the agreement between calculated and observed fluorescences for the 1:1 bzam uranyl titration suggested that fluorescence might be used reliably to study the uranyl acetam system.

For the 10:1 bzam uranyl titration, it was found that the fluorescence intensity predicted using the $\log \mathrm{K}$ values and species fluorescence intensities used to predict the fluorescence intensity for the 1:1 system was too high. This suggested the presence of a further weakly fluorescing species, not considered in the 1:1 bzam uranyl titration, and the most likely choice appeared to be a bis bzam uranyl complex. The existence of a bis uranyl bzam complex is highly likely in view of the isolation of such a complex in crystallographic studies [38]. Inclusion of a bis bzam uranyl complex with $\log \beta_{2}=22.3$ produced a reasonable fit, as seen in Figure 9, with this species appearing to be, like the other uranyl bzam species, weakly fluorescent. The bzam ligand displays a weak CHEF (chelation enhanced fluorescence) effect [58,59] with uranyl, which probably arises from coordination of fluorescence-quenching lone pairs on the bzam ligand with the uranyl cation. The fitting of the model seen in Figure 9 for fluorescence intensities at $514 \mathrm{~nm}$ and bzam:uranyl ratios of 0:1,1:1, and 10:1 was repeated for other peak 
intensities at $555 \mathrm{~nm}, 532 \mathrm{~nm}$, and $490 \mathrm{~nm}$, with similar results. The titration of $5 \times 10^{-6} \mathrm{M}$ uranyl solutions at $\mathrm{pH} 7.66$ with $0.05 \mathrm{M}$ bzam in Figure 10 was used to support the $\log \beta$ values obtained for the uranyl bzam system from the titrations in Figure 9.

The Uranyl acetamidoxime system: $\log \mathrm{K}^{*}$ values for metal:ligand complexes determined by fluorescence can differ from $\log \mathrm{K}$ values determined by absorbance spectroscopy by as much as a $\log$ unit [60]. However, the level of agreement between the $\log \mathrm{K}$ values obtained above for the $\mathrm{UO}_{2}{ }^{2+}$ bzam system by absorbance $(\log \mathrm{K})$ and fluorescence $\left(\log \mathrm{K}^{*}\right)$ suggests that a fluorescence analysis of the $\mathrm{UO}_{2}^{2+}$ acetam system should yield reasonably reliable results. In Figure 11 is seen the fluorescence titration of $5 \times 10^{-6} \mathrm{M} \mathrm{UO}_{2}{ }^{2+}$ with $0.05 \mathrm{M}$ acetam at a constant $\mathrm{pH}$ of 7.38. Also carried out were titrations of $5 \times 10^{-6} \mathrm{M}$ uranyl in the presence of $5 \times 10^{-6} \mathrm{M}$ and $5 \times 10^{-5} \mathrm{M}$ acetam. These titrations were analyzed exactly as was carried out for the corresponding uranyl bzam titrations as described above. This yielded the $\log \mathrm{K}$ values for uranyl acetam complexes given in Table 1. These are similar to those obtained for the corresponding uranyl bzam complexes, except that they are somewhat higher, as would be expected from the greater proton basicity of acetam as compared to bzam. The $\log \beta_{2}$ value of 23.7 for uranyl with acetam is of interest, since it can be compared with the $\log \mathrm{K}_{1}$ values of about 17 reported by Rao et. al. [17] for the bi-amidoxime ligands L1 and L2 in Figure 1. The low values of $\log \mathrm{K}_{1}$ for these biamidoximes suggests that the ligand architecture used has not led to any stability enhancement as compared with binding two acetam ligands to uranyl. This presumably derives, at least in the case of L2, from the long alkane bridge connecting the two amidoxime groups together, which leads to low complex stability arising both from adverse entropic effects [61], as well as steric strain derived from the difficulty of correctly orienting the amidoxime groups for binding to the uranyl ion. In the case of L1, Rao et al. [17] have suggested that binding occurs only through the 
negative $\mathrm{O}$ donors of the ligand, so that the stabilization due to the $\eta^{2}$ binding of the amidoxime groups suggested here for bzam and acetam based on reported structures of their uranyl complexes [38] would not be present. The structure reported [40] for the uranyl complex of L3 shows a bi-amidoxime ligand that has both amidoxime groups bound in a $\eta^{2}$ fashion, so that one might expect a complex of very high thermodynamic stability to be formed by L3 with the uranyl ion.

In addition to difficulties with measuring $\log \mathrm{K}$ values for $\mathrm{UO}_{2}{ }^{2+}$ complexes by fluorescence associated with the fact that these refer to the excited state, and not the ground state, one should also consider the possibility of quenching mechanisms such as collisional quenching [24] or photochemical destruction of the ligand by the highly oxidizing excited state of the uranyl cation [62]. The possibility of collisional quenching was investigated by repeating the titration seen in Figure 10 using the only weakly binding but structurally similar acetamide in place of acetam, with no significant quenching being observed. A variety of alcohols is able to quench uranyl fluorescence, probably by abstraction [62] of $\alpha \mathrm{H}$ atoms. It seems possible that this could occur with acetam, but bzam has no $\alpha \mathrm{H}$ atoms, so that it seems probable that such a mechanism of quenching would not occur. As a further test of the origin of the quenching of the fluorescence of uranyl by ligands, a study was carried out of the quenching of fluorescence by titrating $5 \times 10^{-6} \mathrm{M} \mathrm{UO}_{2}{ }^{2+}$ solutions with $0.05 \mathrm{M} \mathrm{Na}_{2} \mathrm{CO}_{3}$. This produced quenching of the uranyl fluorescence that resembled quite closely that seen in Figure 10 that could be analyzed reasonably well in terms of formation of more weakly fluorescing uranyl carbonato complexes, and the known formation constants [18] for these complexes. A very encouraging result is that an ongoing determination of $\log \mathrm{K}_{1}$ for the ligand PDA [63] (Figure 1) with $\mathrm{UO}_{2}{ }^{2+}$ by both absorbance and fluorescence spectroscopy has produced results in excellent agreement with each 
other, supporting the idea that fluorescence can be used to determine $\log \mathrm{K}_{1}$ values for uranyl complexes, provided that attention is paid to the problems mentioned above.

\section{Structure and stability of uranyl complexes from density functional theory: Theoretical} calculations were performed to elucidate the structure and relative stability of uranyl complexes with acetam and bzam. The most stable geometries of the uranyl complexes with one and two ligands obtained at the M06/SSC/6-311++G(d,p) level of theory are shown in Figure 12. Consistent with previous calculations and X-ray diffraction data [38-40], the $\eta^{2}$ binding with the $\mathrm{N}-\mathrm{O}$ oximate bond to uranyl is the energetically preferred coordination mode for all amidoxime complexes. As was observed previously [35], the most stable structural configuration for 1:1 uranyl complexes with mono and bidentate donor ligands was solely five-coordinate. In contrast, the solid-state configurations of 1:2 uranyl complexes with acetam and bzam attained the coordination number six by having two solvent molecules $\left(\mathrm{CH}_{3} \mathrm{OH}\right)$ in the equatorial plane [38]. Since the preferred coordination number for the corresponding species in water is not yet known, we used theoretical calculations (M06 and SMD) to determine the most stable coordination environment in aqueous solution. Comparison of the relative stabilities of $\left[\mathrm{UO}_{2}(\text { ligand })_{2}\left(\mathrm{H}_{2} \mathrm{O}\right)_{1,2}\right]$ with one and two water molecules based on the equilibrium shown by eq 3

$\left[\mathrm{UO}_{2}(\text { ligand })_{2}\left(\mathrm{H}_{2} \mathrm{O}\right)\right]+\mathrm{H}_{2} \mathrm{O} \rightleftharpoons\left[\mathrm{UO}_{2}(\text { ligand })_{2}\left(\mathrm{H}_{2} \mathrm{O}\right)_{2}\right], \Delta \mathrm{G}_{\mathrm{aq}}(1)$

reveals that the difference in their relative stability is very small, $\Delta \mathrm{G}_{\mathrm{aq}}(1)=0.3-1.0 \mathrm{kcal} / \mathrm{mol}$, which suggests that both forms are likely to coexist in thermodynamic equilibrium in solution.

The quantitative prediction of absolute stability constants for multivalent metal ions poses a formidable challenge, because the solvation free energy of a multivalent ion is not fully 
accounted for by treating only the first hydration shell around a metal ion explicitly [64]. As was determined in our previous work [35], the DFT-based method permitted reasonably good estimates of relative binding strengths for a series of 13 oxygen donor ligands, whereas the absolute complexation energies of uranyl complexes were significantly overestimated. As the formation constants for the uranyl cation with acetam and bzam are accurately measured, we can now apply our computational protocol [35] to calculate the complexation free energies for amidoxime ligands (eq 4) and rank-order their stability in comparison with monovalent oxygen donor ligands.

$$
\left[\mathrm{UO}_{2}\left(\mathrm{H}_{2} \mathrm{O}\right)_{5}\right]^{2+}+\mathrm{n} \text { ligand }^{-} \rightleftharpoons\left[\mathrm{UO}_{2}(\text { ligand })_{\mathrm{n}}\left(\mathrm{H}_{2} \mathrm{O}\right)_{5-2 \mathrm{n}}\right]^{2-\mathrm{n}}+2 \mathrm{n} \mathrm{H}_{2} \mathrm{O}, \Delta \mathrm{G}_{\mathrm{aq}}(2)
$$

The results given in Table 2 indicate that two recommended [35] theoretical methods correctly determine the order of ligand stability, but significantly overestimate the absolute values of $\Delta \mathrm{G}_{\mathrm{aq}}(2)$. We note that the less negative $\Delta \mathrm{G}_{\mathrm{aq}}(2)$ values obtained using the M06 and SMD protocol in comparison with the B3LYP and IEF-PCM protocol is due to generally higher ion solvation free energies predicted with the SMD solvation model [27]. When the computational results for amidoxime ligands are combined with the previously published results for the monovalent negative oxygen donor ligands [35], the resulting plot of computed versus experimental stability constants is linear, as shown in Figure 13. A strong linear correlation with the experimental data suggests that the complexation behavior of both pure $\mathrm{O}-$ and mixed $\mathrm{O}, \mathrm{N}-$ donor ligands is well captured by the applied level of theory and the high uranyl binding constants with amidoxime ligands are to a large extent due to the very high basicity of the 
deprotonated base, but also with a significant input from the binding of the $\mathrm{N}$ donor present in the $\eta^{2}$ bound oxime groups of the ligands.

Uranyl bzam and acetam complexes in solution; The species that are present in solutions of uranyl containing bzam and acetam can be modeled using HySS [22]. The species distribution diagram in Figure 14 shows the species present for a $5 \times 10^{-6} \mathrm{M}$ uranyl solution, with $1.48 \times 10^{-5}$ $\mathrm{M}$ acetam present. The latter is the concentration of acetam at the midpoint of the titration in Figure 11. One sees that at this point in the titration, close to $50 \%$ of the uranyl in solution is present as the acetam species $\mathrm{UO}_{2}(\text { acetam })^{+}$and $\mathrm{UO}_{2}$ (acetam) $\mathrm{OH}^{+}$. The diagram shows that the $\mathrm{UO}_{2}(\text { acetam })^{+}$species is dominant mainly between $\mathrm{pH} 5$ and 7. At a $\mathrm{pH}$ of 8.5 , which is more typical of the $\mathrm{pH}$ of the ocean, the dominant uranyl species is the mono-hydroxy species $\mathrm{UO}_{2}($ acetam $) \mathrm{OH}$, which may be the species present on ion-exchange materials operating at this $\mathrm{pH}$. If the ion-exchange materials used allow for more than one amidoxime group to coordinate to the uranyl, then, as discussed below, the $\mathrm{UO}_{2}$ (acetam $)_{2}$ species might be dominant.

Calculations with HYSS [22] show that for $1.3 \times 10^{-8} \mathrm{M}$ uranyl, the concentration present in seawater [7], the polymeric hydroxo species have virtually completely dissociated. The dominant species present in the ocean, where the carbonate concentration is $0.0025 \mathrm{M}$ [16], and the $\mathrm{pH}$ quite high, are the $\left[\mathrm{UO}_{2}\left(\mathrm{CO}_{3}\right)_{2}\right]^{2-}$ and $\left[\mathrm{UO}_{2}\left(\mathrm{CO}_{3}\right)_{3}\right]^{4-}$ species, and it is with the $\mathrm{CO}_{3}{ }^{2-}$ anion that the amidoxime ligands must contend to bind the $\mathrm{UO}_{2}{ }^{2+}$ cation. In Figure 15 is shown a species distribution diagram calculated with HYSS [22]. The uranyl and carbonate concentrations are kept at $1.3 \times 10^{-8} \mathrm{M}$ and $2.5 \times 10^{-3} \mathrm{M}$, the respective concentrations in seawater [7,16], and the $\mathrm{pH}$ is kept at 8.5 . The $\log \mathrm{K}$ values used for the carbonato complexes of uranyl are those selected by Grenthe et al. [65]. The role of carbonato complexes in the extraction of uranium from seawater has been discussed elsewhere [66]. The concentration of 
acetam is varied across the diagram, ranging from $10^{-8} \mathrm{M}$ to $0.5 \mathrm{M}$. It is seen that below an acetam concentration of $10^{-4} \mathrm{M}$, the carbonate prevails, and little of the acetam complexes of uranyl is formed. Above an acetam concentration of $10^{-2} \mathrm{M}$, the uranyl is present almost entirely as the bis-acetam complex. The significance of Figure 15 for the ability of ion-exchange materials bearing acetam functional groups to extract $\mathrm{UO}_{2}(\mathrm{VI})$ from the oceans may be judged from our estimate that within the volume of water containing the acetam functional groups on the braided polymer material, the concentration of amidoxime groups would be about $0.1 \mathrm{M}$, which should allow for effective extraction of $\mathrm{UO}_{2}(\mathrm{VI})$.

Conclusions: In line with current thinking, the uranyl ion in solution is observed to fluoresce strongly as the trimeric $\left[\left(\mathrm{UO}_{2}\right)_{3} \mathrm{O}(\mathrm{OH})_{3}\right]^{+}$species, which is the dominant solution species between $\mathrm{pH} 5$ and 9 for $5 \times 10^{-6} \mathrm{M}$ uranyl solutions (Figure 2) [18]. It appears that other polymeric uranyl solution species sharing the structural motif of an oxide ion surrounded by three uranyl groups found in $\left[\left(\mathrm{UO}_{2}\right)_{3} \mathrm{O}(\mathrm{OH})_{3}\right]^{+}$, present in the same $\mathrm{pH}$ range, but in lower concentrations than $\left[\left(\mathrm{UO}_{2}\right)_{3} \mathrm{O}(\mathrm{OH})_{3}\right]^{+}$, may also fluoresce strongly. The monomeric uranyl hydroxo species $\left[\mathrm{UO}_{2}(\mathrm{OH})\right]^{+},\left[\mathrm{UO}_{2}(\mathrm{OH})_{2}\right],\left[\mathrm{UO}_{2}(\mathrm{OH})_{3}\right]^{-}$and $\left[\mathrm{UO}_{2}(\mathrm{OH})_{4}\right]^{2-}$ fluoresce only weakly, as is also the case for dimeric species such as $\left[\left(\mathrm{UO}_{2}\right)_{2}(\mathrm{OH})_{2}\right]^{2+}$. Absorbance studies of the bzam complexes of $\mathrm{UO}_{2}{ }^{2+}$, utilizing the intense $\pi \rightarrow \pi^{*}$ transitions of the bzam ligand, yield $\log \mathrm{K}$ values for the uranyl bzam complexes. The intense fluorescence of the uranyl species in solution is decreased steadily with increasing concentrations of bzam or acetam. Analysis of these titrations yields $\log \mathrm{K}$ values for bzam in good agreement with those obtained from the absorbance studies, suggesting that fluorescence can be used to determine log $\mathrm{K}$ for the uranyl amidoxime systems. This is in spite of the problem that $\log \mathrm{K}$ values determined by fluorescence refer to excited state species, and may not correspond well with ground state species [23,24]. 
DFT calculations appear able to predict the correct sequence of $\log \mathrm{K}$ values for a variety of $\mathrm{O}$ donor ligands, and suggest that the high $\log \mathrm{K}_{1}$ values for bzam and acetam with uranyl derive from the high basicity of the ligands. There is also a significant input from the binding of the $\mathrm{N}$ donor present in the $\eta^{2}$ bound oxime groups of the ligands. The $\log \mathrm{K}$ values obtained for acetam and bzam suggest that a braided polymer with acetam or bzam type functional groups attached should extract uranyl ion very strongly from the ocean, even in competition with the strongly complexing carbonate ion present at quite high concentration.

Acknowledgements: This research was supported by the U.S. DOE Office of Nuclear Energy. 


\section{References and Notes.}

1) L. Rao, "Recent International R\&D Activities in the Extraction of Uranium from Seawater," Lawrence Berkeley National Laboratory, 5 Jan 2011.

2) "Analysis of the Uranium Supply to 2050," International Atomic Energy Agency, STI/PUB/1104, May 2001.

3) M. Kanno, J. Nucl. Sci. Technol., 21 ( 1984) 1.

4) A. M. Macfarlane, M. Miller, Elements, 3 (2007) 185.

5) N. Seko, M. Tamada, F. Yoshii, Nucl. Instrum. Meth. Physics Res., B236 (2005) 21.

6) J. Kim, C. Tsouris, R. T. Mayes, Y. Oyola, T. Saito, C. J. Janke, S. Dai, E. Schneider, D. Sachde, Sep. Sci. Technol., 48 (2013) 367.

7) N. Seko et al., Nucl. Technol., 144 (2003) 274.

8) H. Sodaye, S. Nisan, C. Poletiko, S. Prabhakar, P. K. Tewari, Desalination, 235 (2009) 9.

9) R. Khamizov, D. M. Muraview, A. Warshawsky,"Recovery of Valuable Mineral Components from Seawater by Ion-Exchange and Sorption Methods," in Ion Exchange and Solvent Extraction: A Series of Advances, Vol. 12, J. A. Marinsky, Y. Marcus, Y. (Eds.) CRC Press, 1995.

10) H. J. Schenk, L. Astheimer, E. G. Witte, K. Schwochau, Sep. Sci. Technol., 17 (1982) 1293.

11) L. Astheimer, H. J. Schenk, E. G. Witte, K. Schwochau, K. Sep. Sci. Technol., 18 (1983) 307.

12) T. Hirotsu, S. Katch, K. Sugasaka, J. Chem. Soc., Dalton Trans., (1986) 1609.

13) K. Sugasaka, S. Katoh, N. Takai, H. Takahashi, Y. Umezawa, Sep. Sci. Technol., 16 (1981) 971. 
14) S. Katoh, K. Sugasaka, K. Sakane, N. Takai, H. Takahashi, Y. Umezawa, T. Itagaki, Nippon Kagaku Kaishi, 1449 (1982) 1455.

15) T. Hirotsu, S. Katoh, K. Sugasaka, M. Seno, T. Itagaki, J. Chem. Soc. Dalton Trans., (1986) 1983.

16) R. Chester, T. D. Jickells, Marine Geochemistry. $3^{\text {rd }}$ Edition, Wiley-Blackwell Publishing, New York, 2012.

17) G. Tian, S. Teat, L. Rao, Dalton Trans., 42 (2013) 5690.

18) I. Grenthe, J. Drozdzynski, T. Fujino, E. C. Buck, T. E. Albrecht-Schmitt, S. F. Wolf, The chemistry of the actinide and transactinide elements, 3rd ed., L. R. Morss, N. M. Edelstein, J., Fuger, (eds.). Springer: Netherlands, 2006, Vol. 1, p. 599.

19) I. Grenthe, J. Fuger, R. J. M. Konings, R. J. Lemire, A. B. Muller, C. Nguyen-Trung, H. Wanner, Chemical Thermodynamics of Uranium, NEA/OECD, North Holland, 1992.

20) R. Guillamont, T. Fanghänel, J. Fuger, I. Grenthe, D. Palmer, M. Rand, V. Neck, Chemical Thermodynamics of Uranium, Neptunium, Plutonium, Americium, and Technetium, NEA/OECD, North Holland, 2003.

21) C. F. Baes, R. E. Mesmer, The Hydrolysis of Cations, John Wiley, New York, 1976.

22) L. Alderighi, P. Gans, A. Ienco, D. Peters, A. Sabatini, A. Vacca, Coord. Chem. Rev., 184 (1999) 311.

23) I. Billard, K. Lutzenkirchen, Radiochim. Acta, 91 (2003) 285.

24) J. R. Lakowicz, Principles of Fluorescence Spectroscopy, $3^{\text {rd }}$ Edition., Springer, New York, 2006.

25) D. Kovács, J. Wölfling, N. Szabó, M. Szécsi, I. Kovács, I. Zupkó, É, Frank, Eur. J. Med. Chem., 70 (2013) 649. 
26) R. García-Álvarez, A. E. Díaz-Álvarez, J. Borge, P. Crochet, V. Cadierno, Organometallics, 31(2012) 6482.

27) N. Mehio, M. A. Lashley, J. W. Nugent, L. Tucker, B. Correia, C.-H. Do-Thanh, S. Dai, R. D. Hancock, V. S. Bryantsev, J. Phys. Chem., 119 (2015) 3567.

28) E. J. Billo, EXCEL for Chemists, Wiley-VCH, New York, 2001.

29) Gaussian 09, Revision C.01, M. J. Frisch, G. W. Trucks, H. B. Schlegel, G. E. Scuseria, M. A. Robb, J. R. Cheeseman, G. Scalmani, V. Barone, B. Mennucci, G. A. Petersson, H. Nakatsuji, M. Caricato, X. Li, H. P. Hratchian, A. F. Izmaylov, J. Bloino, G. Zheng, J. L. Sonnenberg, M. Hada, M. Ehara, K. Toyota, R. Fukuda, J. Hasegawa, M. Ishida, T. Nakajima, Y. Honda, O. Kitao, H. Nakai, T. Vreven, J. A. Montgomery, Jr., J. E. Peralta, F. Ogliaro, M. Bearpark, J. J. Heyd, E. Brothers, K. N. Kudin, V. N. Staroverov, R. Kobayashi, J. Normand, K. Raghavachari, A. Rendell, J. C. Burant, S. S. Iyengar, J. Tomasi, M. Cossi, N. Rega, J. M. Millam, M. Klene, J. E. Knox, J. B. Cross, V. Bakken, C. Adamo, J. Jaramillo, R. Gomperts, R. E. Stratmann, O. Yazyev, A. J. Austin, R. Cammi, C. Pomelli, J. W. Ochterski, R. L. Martin, K. Morokuma, V. G. Zakrzewski, G. A. Voth, P. Salvador, J. J. Dannenberg, S. Dapprich, A. D. Daniels, Ö. Farkas, J. B. Foresman, J. V. Ortiz, J. Cioslowski, D. J. Fox, Gaussian, Inc., Wallingford CT, 2009.

30) (a) A. D. Becke, Chem. Phys., 98 (1993) 5648. (b) C. Lee, W. Yang, R. G. Parr, Phys. Rev., B, 37 (1988) 785.

31) Y. Zhao, D. G. Truhlar, Theor. Chem. Acc., 120, (2008) 215.

32) M. Dolg, H. Stoll, H. Preuss, R. M. Pitzer, J. Phys. Chem., 97 (1993) 5852. 
33) (a) S. Miertus, E. Scrocco, J. Tomasi, Chem. Phys., 55 (1981) 117. (b) E. Cances, B. Mennucci, J. Tomasi, J. Chem. Phys., 107 (1997) 3032. (c) B. Mennucci, E. Cances, J. Tomasi, J. Phys. Chem. B, 101 (1997) 10506.

34) A. Marenich, C. J. Cramer, D. G. Truhlar, J. Phys. Chem. B, 113 (2009) 6378.

35) S. Vukovic, B. P. Hay, V. S. Bryantsev, Inorg. Chem., 54 (2015) 3995.

36) A. E. Martell, and R. M. Smith, Critical Stability Constant Database, 46, National Institute of Science and Technology (NIST), Gaithersburg, MD, USA, 2003.

37) Cambridge Structural Database, Cambridge Crystallographic Data Centre, 12 Union Road, Cambridge CB2 1EZ, United Kingdom.

38) S. Vukovic, L. A. Watson, S. O. Kang, R. Custelcean, B. P. Hay, Inorg. Chem., 51 (2012) 3855.

39) P. S. Barber, S. P. Kelley, R. D. Rogers, RSC Advances, 2, 2012, 8526.

40) S. P. Kelley, P. S. Barber, P. H. K. Mullins, R. D. Rogers, Chem. Commun., 50 (2014) 12504.

41) G. Meinrath, J. Radioanal. Nucl. Chem., 224 (1997) 119.

42) R. G. Denning, Struct. Bond., 79 (1992) 215.

43) J. C. Eisenstein, M. H. L Pryce, Proc. Royal Soc. (London), A229 (1955) 20.

44) P. Brint, A. J. McCaffery, Mol. Phys., 25, (1973) 311.

45) R. L. DeKock, E. J. Baerends, P. M. Boerrigter, J. G. Snijders, Chem. Phys. Lett., 105, (1984) 308 .

46) R. G. Denning, T. R. Snellgrove, D. R. Woodwark, Mol. Phys., 32 (1976) 419.

47) S. Tsushima, A. Rossberg, A. Ikeda, K. Muller, A. C. Scheinost, Inorg. Chem., 46 (2007) 10819. 
48) M. Åberg, Acta Chem. Scand., A32 (1978) 101; 23 (1969) 791; 24 (1970) 2901.

49) A. Navaza, F. Villain, P. Charpin, Polyhedron, 3 (1984) 143.

50) P. Nockermann, K. Servaes, R. Van Deun, K. Van Hecke, L. Van Meervelt, K. Binnemans, C. Gorller-Walrand, Inorg. Chem., 46 (2007) 11335.

51) P. Thuery, Cryst. Growth. Des., 11 (2011) 3282.

52) P. Thuery, Cryst. Growth. Des., 8 (2008) 4132.

53) O. A. Geras'ko, D. G. Samsonenko, A. A. Sharanova, A. V. Virovets, J. Lipkowski, V. P. Fedin, Izv, Akad. Nauk SSSR, Ser. Khim. (2002) 325.

54) M.-J. Crawford, P. Mayer, H. Noth, M. Suter, Inorg. Chem., 43 (2004) 6860.

55) Z. Fazekas, H. Tomiyasu, I.-L. Park, T. Yamamura, M. Harada, Models in Chemistry, 135 (1998) 783, Akademiai, Kiadó, Budapest.

56) C. Nguyen-Trung, D. A. Palmer, G. M. Begun, C. Peiffert, R. E. Mesmer, J. Solution Chem., $29(2000) 101$.

57) P. Charpin, M. Lance, M. Nierlich, D. Vigner, C. Musikas, Acta Crystallogr., Sect. C.: Cryst. Struct. Commun., 42 (1986) 1691.

58) A. P. De Silva, H. Q. N. Gunaratne, T. Gunnlaugsen, A. J. M. Huxley, C. McCoy, J. T. Rademacher, T. E. Rice, Chem. Rev., 97 (1997) 1515.

59) R. D. Hancock, Chem. Soc. Rev., 42 (2013) 1500.

60) A. N. Carolan, A. E. Mroz, M. El Ojaimi, D. G. VanDerveer, R. P. Thummel, R. D. Hancock, Inorg. Chem. 51 (2012) 3007.

61) R. D. Hancock, A. E. Martell, Chem. Rev., 89 (1989) 1875.

62) H. D. Burrows, T. J. Kemp, Chem. Soc. Rev., 3, (1974) 139.

63) N. E. Dean, R. D. Hancock, C. L. Cahill, M. Frisch, Inorg. Chem, 47 (2008) 2000. 
64) V. S. Bryantsev, M. S. Diallo, W. A. Goddard III., J. Phys. Chem. A, 113 (2009) 9559.

65) I. Grenthe, J. Drozdzynski, T. Fujino, E. C. Buck, T. E. Albrecht-Schmitt, S. F. Wolf, The chemistry of the actinide and transactinide elements, 3rd ed., L. R. Morss, N. M. Edelstein, J. Fuger, (eds.). Springer: Netherlands, 2006, Vol. 1, p. 601.

66) R. V. Davies, J. Kennedy, R. W. McIlroy, R. Spence, K. M. Hill, Nature, 203 (1964) 1110. 


\section{TABLES}

Table 1. Protonation constants and formation constants with $\mathrm{UO}_{2}{ }^{2+}$ for bzam and acetam at $25{ }^{\circ} \mathrm{C}$ in aqueous solution at ionic strength $(\mu)=0$, as well as formation constants for hydroxy species used in modeling the $\mathrm{UO}_{2}{ }^{2+}$ solution systems.

\begin{tabular}{|c|c|c|c|c|}
\hline Equilibrium & & & $\log K$ & references \\
\hline $\mathrm{H}^{+}+\mathrm{OH}^{-}$ & $\leftrightarrows$ & $\mathrm{H}_{2} \mathrm{O}$ & 14.00 & 36 \\
\hline bzam $^{-}+\mathrm{H}^{+}$ & $\leftrightarrows$ & bzamH & 12.36 & 27 \\
\hline bzamH $+\mathrm{H}^{+}$ & $\leftrightarrows$ & bzamH $_{2}^{+}$ & 4.85 & 27 \\
\hline $\mathrm{UO}_{2}^{2+}+$ bzam $^{-}$ & $\leftrightarrows$ & $\mathrm{UO}_{2}(\mathrm{bzam})^{+}$ & $12.4(1)$ & this work \\
\hline $\mathrm{UO}_{2}^{2+}+2$ bzam $^{-}$ & $\leftrightarrows$ & $\mathrm{UO}_{2}(\text { bzam })_{2}$ & $22.3(1)$ & this work \\
\hline $\mathrm{UO}_{2}\left(\mathrm{bzam}^{+}+\mathrm{OH}^{-}\right.$ & $\leftrightarrows$ & $\mathrm{UO}_{2}($ bzam $) \mathrm{OH}$ & $6.9(1)$ & this work \\
\hline $\operatorname{acetam}^{-}+\mathrm{H}^{+}$ & $\leftrightarrows$ & acetamH & 13.21 & 27 \\
\hline $\operatorname{acetam} \mathrm{H}+\mathrm{H}^{+}$ & $\leftrightarrows$ & $\operatorname{acetamH}_{2}^{+}$ & 5.78 & 27 \\
\hline $\mathrm{UO}_{2}^{2+}+\operatorname{acetam}^{-}$ & $\leftrightarrows$ & $\mathrm{UO}_{2}(\operatorname{acetam})^{+}$ & $13.6(1)$ & this work \\
\hline $\mathrm{UO}_{2}(\operatorname{acctam})^{+}+\mathrm{OH}^{-}$ & $\leftrightarrows$ & $\mathrm{UO}_{2}($ acetam $) \mathrm{OH}$ & $6.8(1)$ & this work \\
\hline $\mathrm{UO}_{2}^{2+}+2$ acetam $^{-}$ & $\leftrightarrows$ & $\mathrm{UO}_{2}(\text { acetam })_{2}$ & $23.7(1)$ & this work \\
\hline $\mathrm{UO}_{2}^{2+}+\mathrm{OH}^{-}$ & $\leftrightarrows$ & $\mathrm{UO}_{2}(\mathrm{OH})^{+}$ & 8.75 & $18-21$ \\
\hline $\mathrm{UO}_{2}^{2+}+2 \mathrm{OH}^{-}$ & $\leftrightarrows$ & $\mathrm{UO}_{2}(\mathrm{OH})_{2}$ & 15.85 & $18-21$ \\
\hline $\mathrm{UO}_{2}^{2+}+3 \mathrm{OH}^{-}$ & $\leftrightarrows$ & $\mathrm{UO}_{2}(\mathrm{OH})_{3}^{-}$ & 21.8 & $18-21$ \\
\hline $\mathrm{UO}_{2}^{2+}+4 \mathrm{OH}^{-}$ & $\leftrightarrows$ & $\mathrm{UO}_{2}(\mathrm{OH})_{4}^{2-}$ & 23.6 & $18-21$ \\
\hline $2 \mathrm{UO}_{2}^{2+}+\mathrm{OH}^{-}$ & $\leftrightarrows$ & $\left(\mathrm{UO}_{2}\right)_{2}(\mathrm{OH})^{3+}$ & 11.3 & $18-21$ \\
\hline $2 \mathrm{UO}_{2}^{2+}+2 \mathrm{OH}^{-}$ & $\leftrightarrows$ & $\left(\mathrm{UO}_{2}\right)_{2}(\mathrm{OH})_{2}^{2+}$ & 22.4 & $18-21$ \\
\hline $3 \mathrm{UO}_{2}^{2+}+5 \mathrm{OH}^{-}$ & $\leftrightarrows$ & $\left(\mathrm{UO}_{2}\right)_{3} \mathrm{O}(\mathrm{OH})_{3}^{+}$ & 54.4 & $18-21$ \\
\hline $3 \mathrm{UO}_{2}^{2+}+7 \mathrm{OH}^{-}$ & $\leftrightarrows$ & $\left(\mathrm{UO}_{2}\right)_{3} \mathrm{O}(\mathrm{OH})_{5}^{-}$ & 65.3 & $18-21$ \\
\hline $4 \mathrm{UO}_{2}^{2+}+7 \mathrm{OH}^{-}$ & $\leftrightarrows$ & $\left(\mathrm{UO}_{2}\right)_{4} \mathrm{O}(\mathrm{OH})_{5}^{+}$ & 76.1 & $18-21$ \\
\hline $\mathrm{UO}_{2}^{2+}+2 \mathrm{OH}^{-}$ & $\leftrightarrows$ & $\left(\mathrm{UO}_{2}\right)(\mathrm{OH})_{2}(s)$ & -22.0 & 36 \\
\hline
\end{tabular}


Table 2. The calculated complexation free energies $\left(\Delta \mathrm{G}_{\mathrm{aq}}\right)$ of $\mathrm{UO}_{2}{ }^{2+}$ with acetam and bzam $(\mathrm{kcal} / \mathrm{mol})$. The computed $\Delta \mathrm{G}_{\mathrm{aq}}$ values were obtained at the B3LYP/SSC/6-311++G(d,p) level with IEF-PCM solvent corrections and at the M06/SSC/6-311++G(d,p) level with SMD solvent corrections. $^{\text {a }}$

\begin{tabular}{lccc}
\hline ligand & $\mathrm{UO}_{2}{ }^{2+}$ :ligand & $\mathrm{B} 3 \mathrm{LYP}$ and IEF-PCM & M06 and SMD \\
\hline acetam & $1: 1$ & $-53.3^{\mathrm{b}}$ & $-33.0^{\mathrm{b}}$ \\
& $1: 2$ & -90.3 & -56.5 \\
bzam & $1: 1$ & -46.6 & -29.8 \\
& $1: 2$ & -82.7 & -52.2
\end{tabular}

${ }^{\mathrm{a}}$ Calculated as free energy changes for reaction 2 using the methodology described in ref [35]. Frequency and all solvation calculations were performed at the B3LYP/SSC/6-31+G(d) level. ${ }^{\mathrm{b}}$ Taken from ref. [35]. 
FIGURES
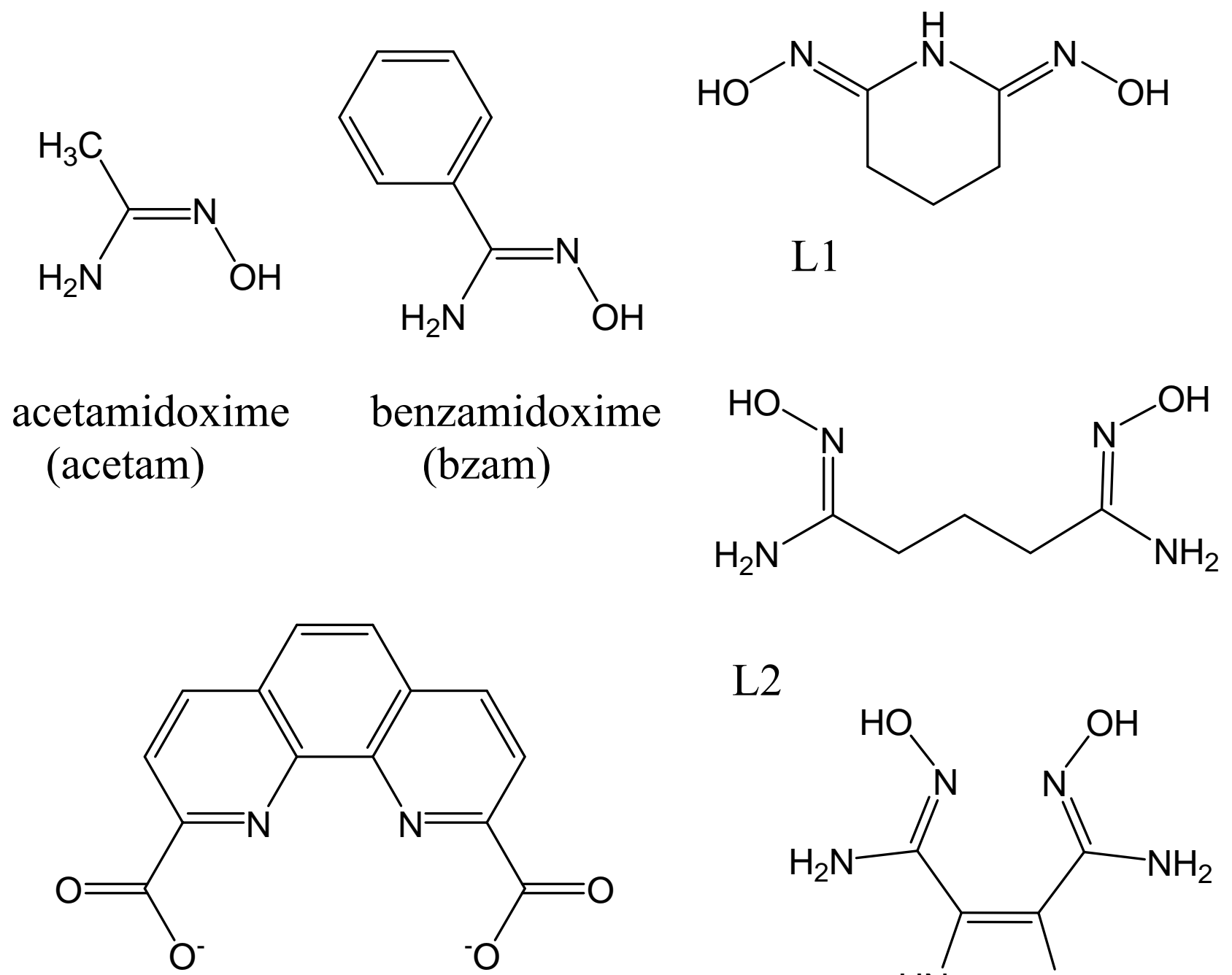

L2
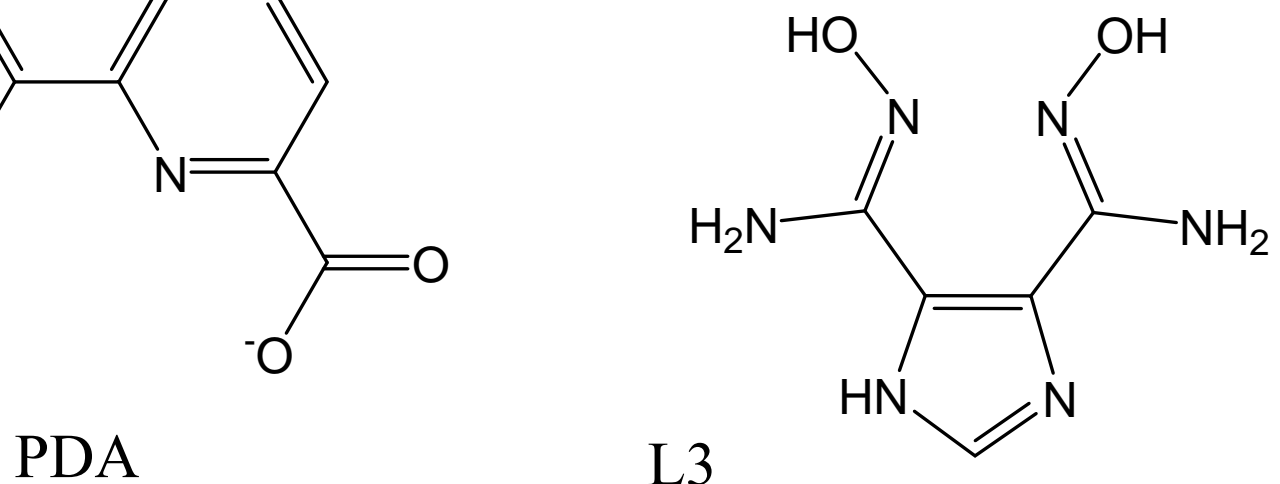

Figure 1. Ligands discussed in this paper. 


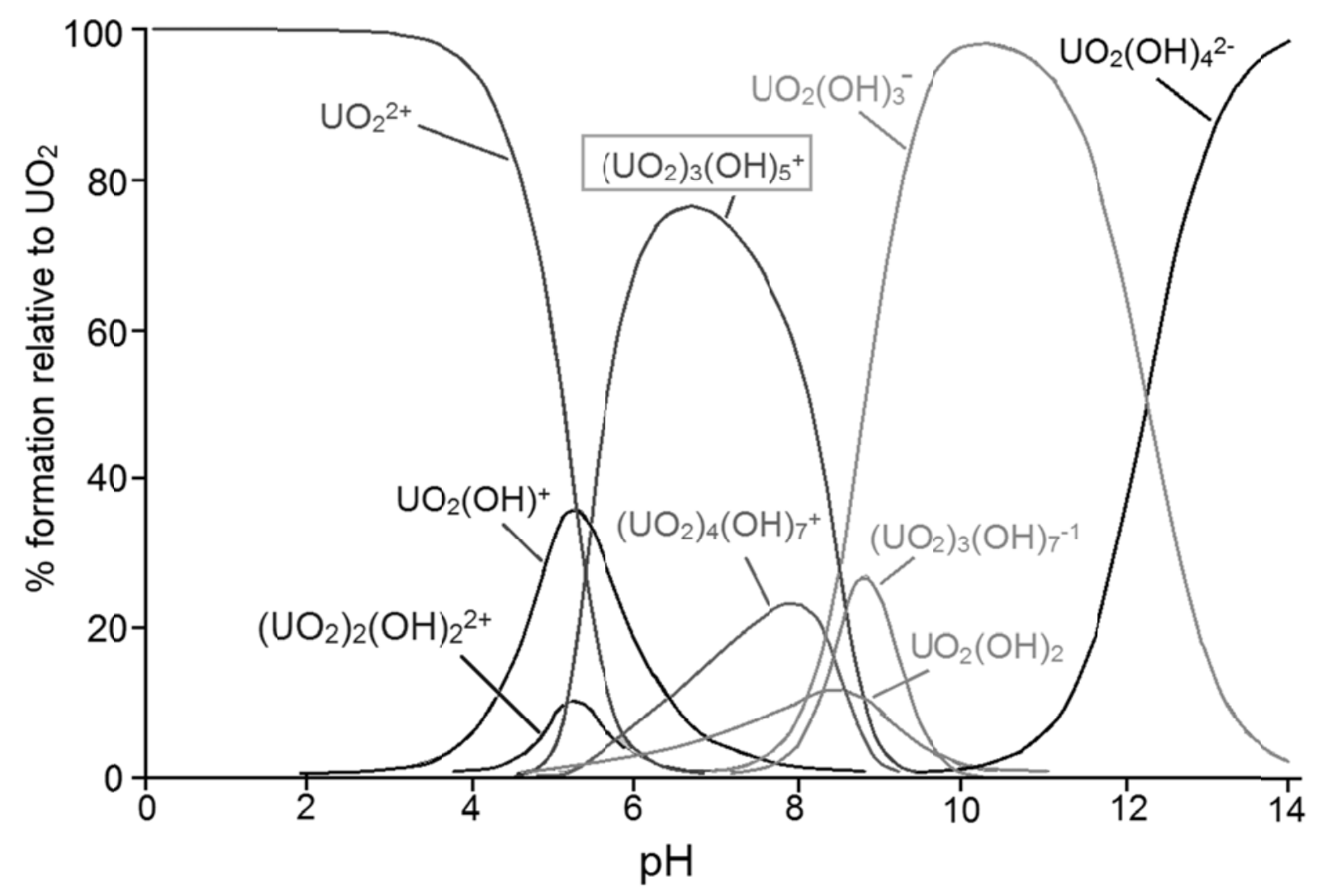

Figure 2. Species distribution diagram between $\mathrm{pH} 2$ and 14 for the $\mathrm{UO}_{2}{ }^{2+}$ cation with total concentration of $\mathrm{UO}_{2}(\mathrm{VI})$ containing species at $5 \times 10^{-6} \mathrm{M}$. The diagram was generated using the program HySS [22] and hydrolysis constants for the $\mathrm{UO}_{2}{ }^{2+}$ cation reported at ionic strength zero and $25^{\circ} \mathrm{C}$ in reference [18]. Note that the species treated as $\left[\left(\mathrm{UO}_{2}\right)_{3}(\mathrm{OH})_{5}\right]^{+},\left[\left(\mathrm{UO}_{2}\right)_{3}(\mathrm{OH})_{7}\right]^{-1}$ and $\left[\left(\mathrm{UO}_{2}\right)_{4}(\mathrm{OH})_{7}\right]^{+}$by HYSS are suggested, as discussed in the text, to be better regarded as the proton-equilibrium equivalent oxide-centered species $\left[\left(\mathrm{UO}_{2}\right)_{3} \mathrm{O}(\mathrm{OH})_{3}\right]^{+},\left[\left(\mathrm{UO}_{2}\right)_{3} \mathrm{O}(\mathrm{OH})_{5}\right]^{-1}$ and $\left[\left(\mathrm{UO}_{2}\right)_{4} \mathrm{O}_{2}(\mathrm{OH})_{3}\right]^{+}$. 


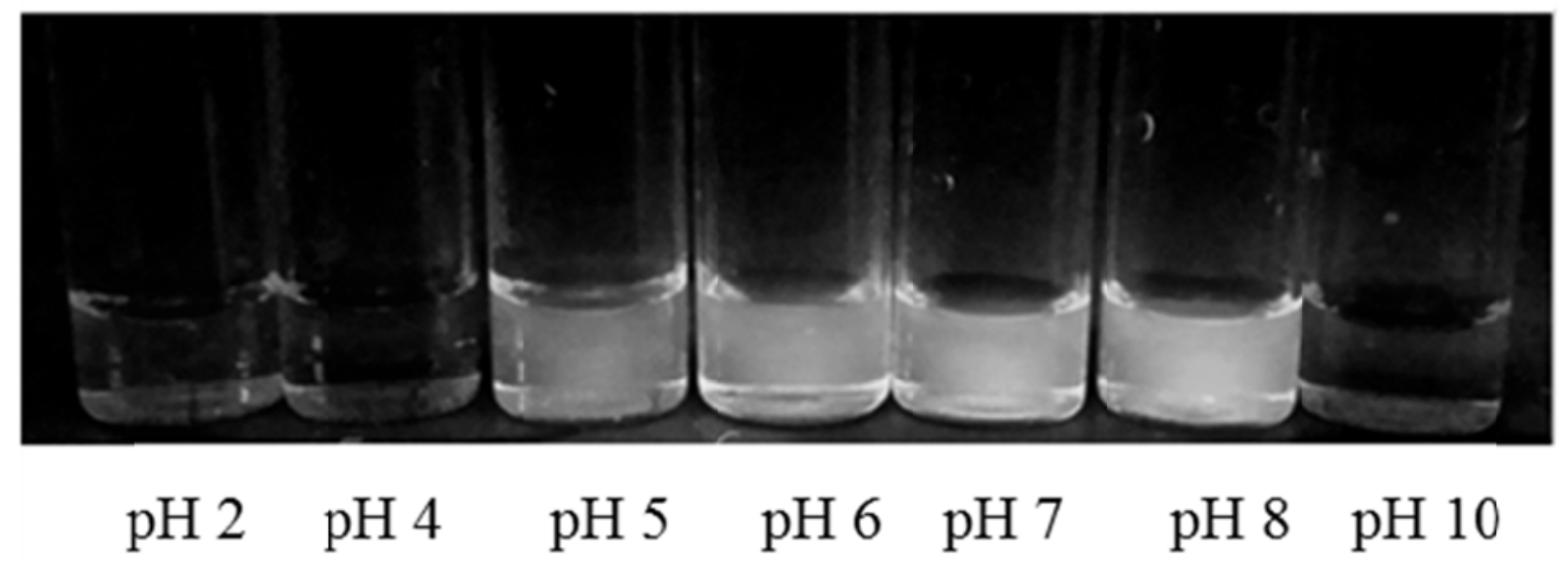

Figure 3. Fluorescence of $10^{-4} \mathrm{M}$ solutions of $\mathrm{UO}_{2}\left(\mathrm{NO}_{3}\right)_{2}$ in aqueous solutions at the $\mathrm{pH}$ values indicated. The $\mathrm{pH}$ region of intense fluorescence corresponds to the region of dominance of the $\left(\mathrm{UO}_{2}\right)_{3} \mathrm{O}(\mathrm{OH})_{3}{ }^{+}$trimer as seen in Figure 2, where it is labeled as $\left(\mathrm{UO}_{2}\right)_{3}(\mathrm{OH})_{5}{ }^{+}$. 


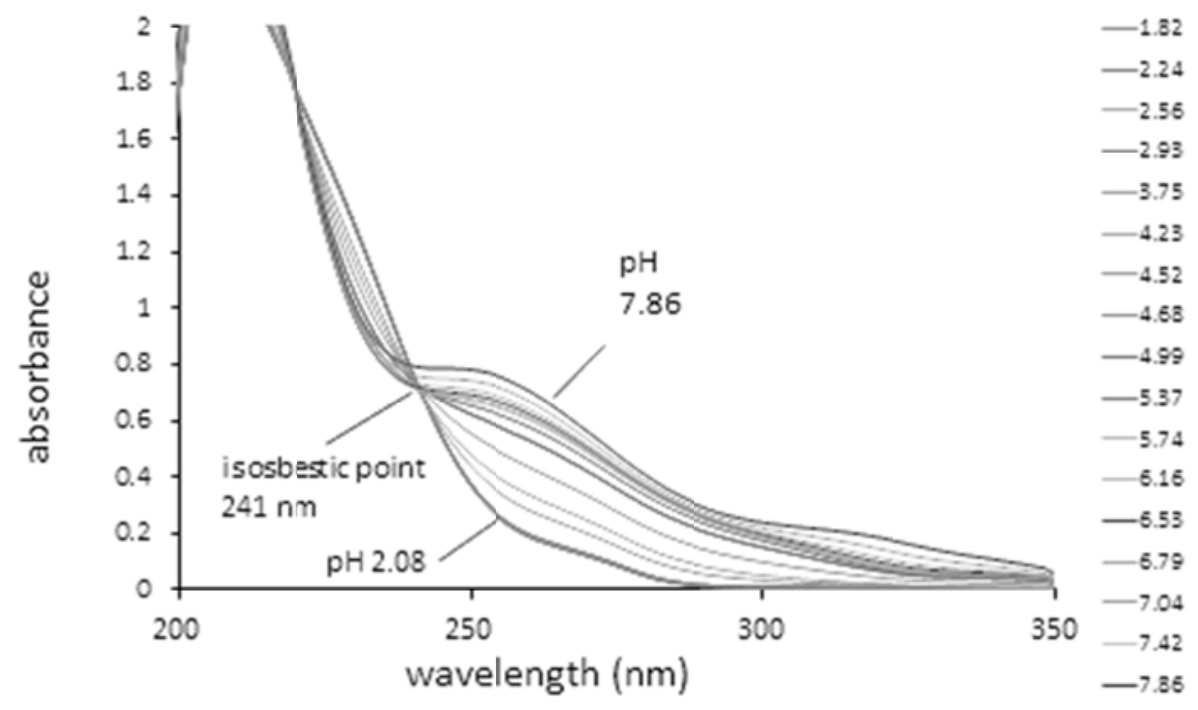

Figure 4. Spectra of $1 \times 10^{-4} \mathrm{M}$ benzamidoxime aqueous solutions in the presence of $1 \times 10^{-4} \mathrm{M}$ $\mathrm{UO}_{2}{ }^{2+}$ in the $\mathrm{pH}$ range $2.08-7.86$ at $25^{\circ} \mathrm{C}$. 


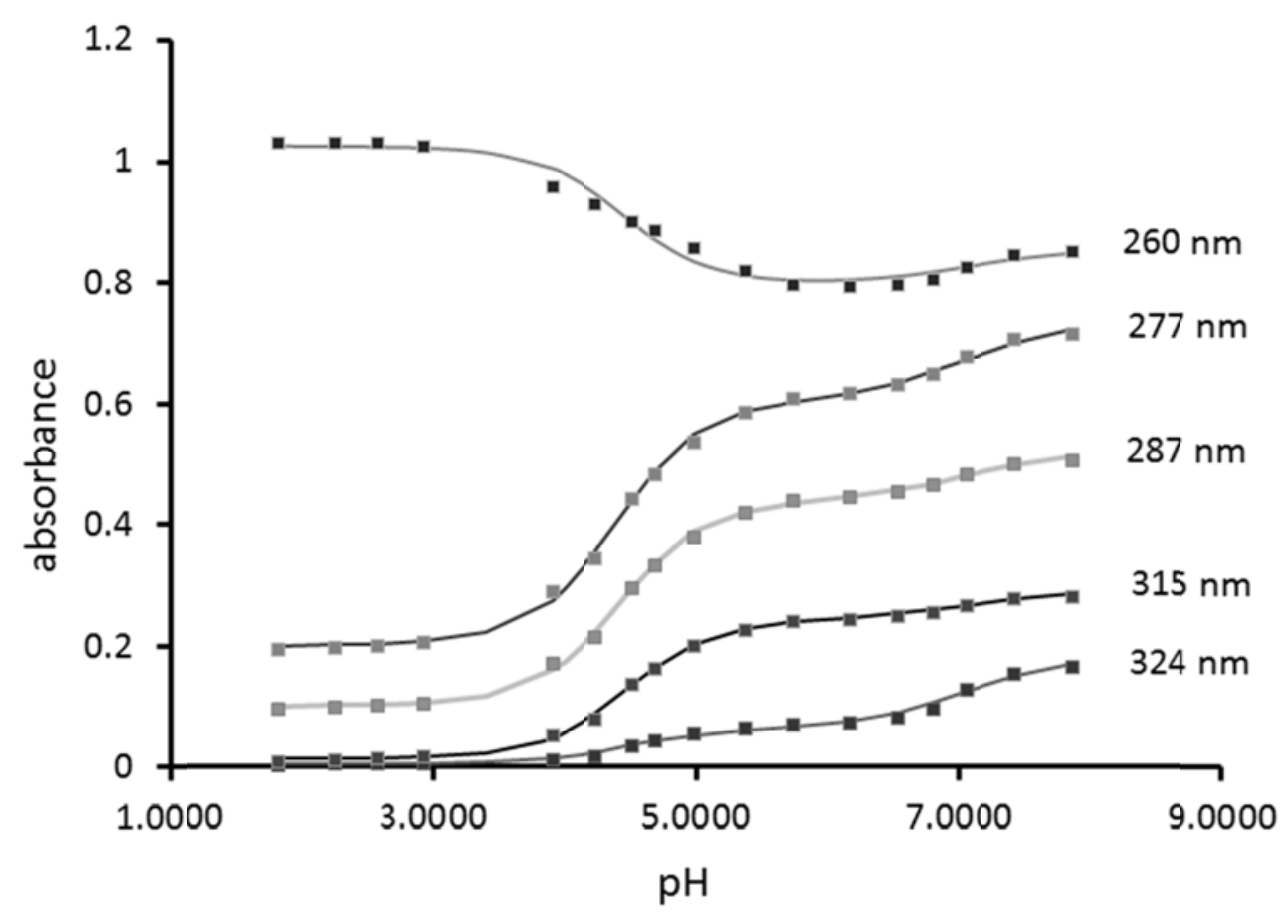

Figure 5. Variation of absorbance as a function of $\mathrm{pH}$ at five different wavelengths of a 1:1 solution of $1 \times 10^{-4} \mathrm{M} \mathrm{UO}_{2}{ }^{2+}$ and benzamidoxime in the $\mathrm{pH}$ range 2.0 to 8.0 at $25^{\circ} \mathrm{C}$. The solid points are experimental values, while the solid lines are theoretical curves fitted as described in the text. 


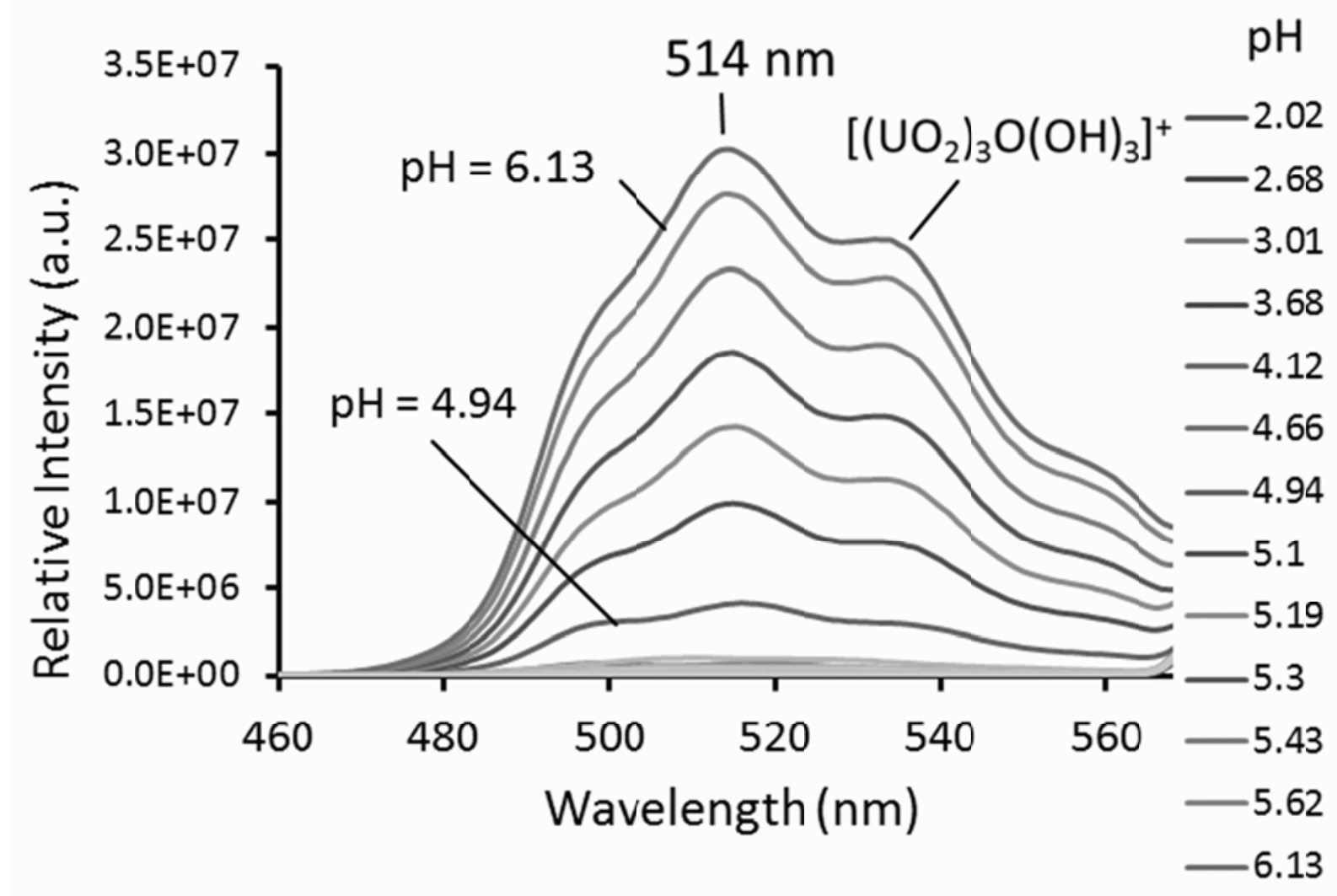

Figure 6. Fluorescence spectra of the $\mathrm{UO}_{2}{ }^{2+}$ cation $\left(5 \times 10^{-5} \mathrm{M}\right)$ in the $\mathrm{pH}$ range $2.02-6.13$. The maximum peak intensity is indicated at $514 \mathrm{~nm}$. Wavelength of excitation $=290 \mathrm{~nm}$. 


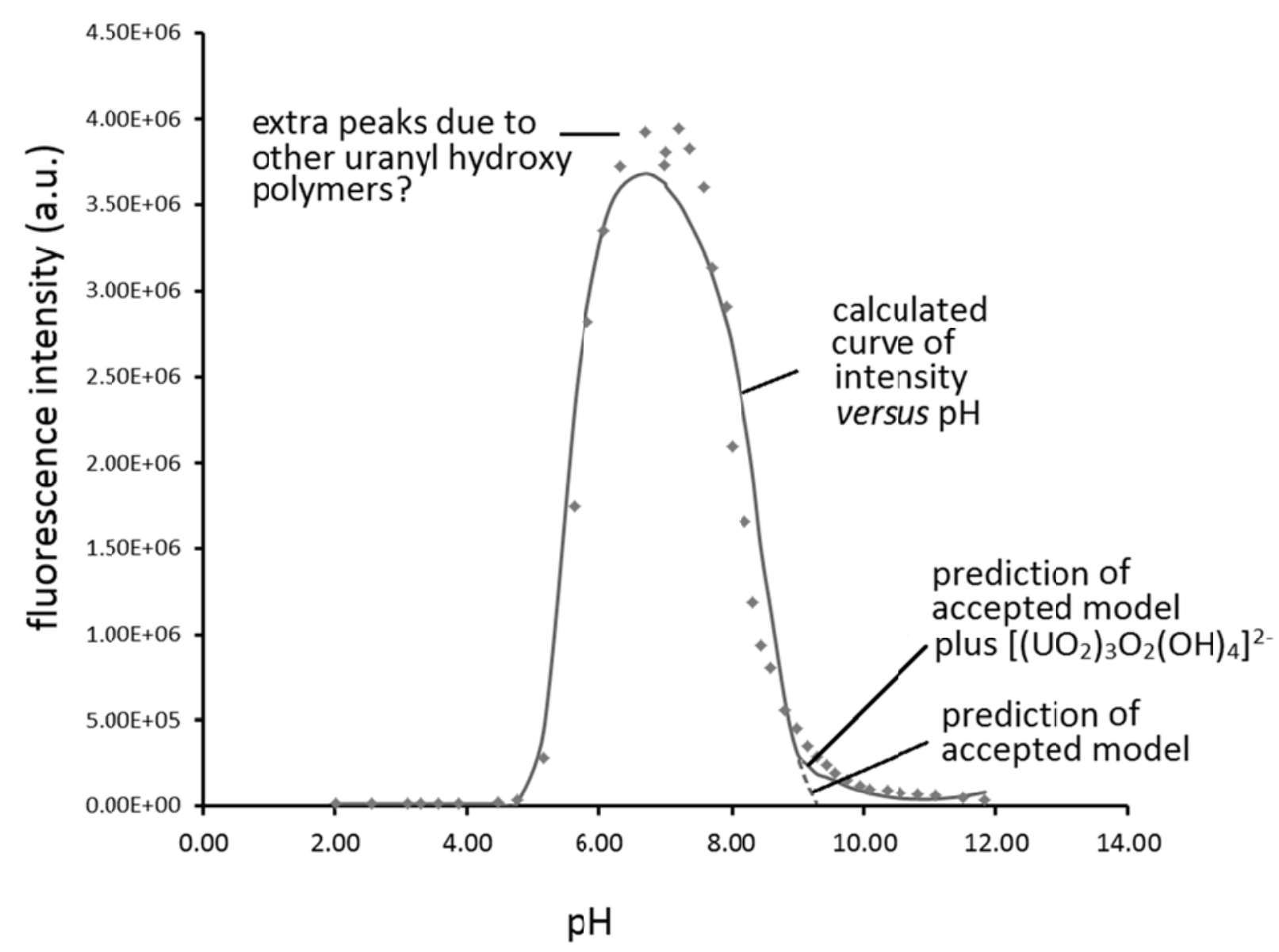

Figure 7. Variation of fluorescence intensity at $514 \mathrm{~nm}$ of a $5 \times 10^{-6} \mathrm{M} \mathrm{UO}_{2}{ }^{2+}$ solution (as $\left.\mathrm{UO}_{2}\left(\mathrm{NO}_{3}\right)_{2}\right)$ as function of $\mathrm{pH}$. This concentration is used since calculations using HySS [22] suggest that no $\mathrm{UO}_{2}(\mathrm{OH})_{2}(s)$ precipitate will form. The dark colored points are the experimental points for fluorescence intensity as a function of $\mathrm{pH}$. The solid line is a curve of fluorescence intensity as a function of $\mathrm{pH}$ fitted to the experimental points, as described in the text, on the basis of $\log \beta$ values for the formation of the hydroxy complexes given in reference [18] (the 'accepted model') and also [19-21]. The curve also includes a $\log \beta$ value for the $\left[\left(\mathrm{UO}_{2}\right)_{3} \mathrm{O}_{2}(\mathrm{OH})_{4}\right]^{2-}$ species, not present in the accepted model, but detected by Raman spectroscopy [49], and suggested here as being of the type of hydroxide-rich species that could account for the fluorescence behavior between $\mathrm{pH} 9$ and 12. Wavelength of excitation $=290 \mathrm{~nm}$. 

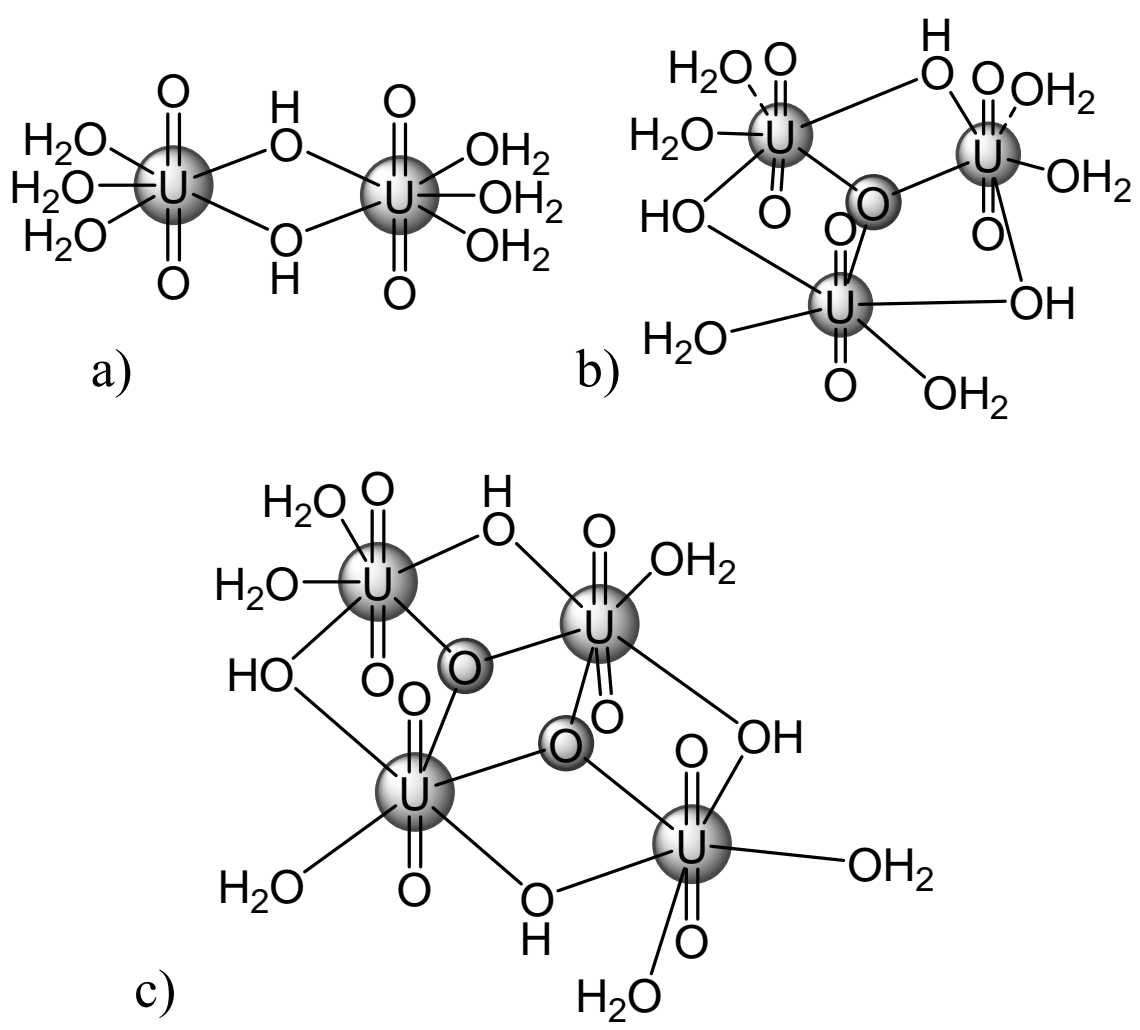

Figure 8. Diagrammatic representations of some polymeric uranyl hydroxo species based on literature structures in the CSD [37] and elsewhere [48]. Structure a) represents those observed for $\left[\left(\mathrm{UO}_{2}\right)_{2}(\mathrm{OH})_{2}\left(\mathrm{H}_{2} \mathrm{O}\right)_{6}\right]^{2+}$ by Åberg [48], and by others with organic counterions [49,50]. Structure b) $\left[\left(\mathrm{UO}_{2}\right)_{3} \mathrm{O}(\mathrm{OH})_{3}\left(\mathrm{H}_{2} \mathrm{O}\right)_{6}\right]^{+}$is that reported by $\AA$ berg [48]. This is a common type of motif, with three uranyl groups surrounding a central oxide anion: some 54 structures are reported in the CSD that contain this motif with a variety of ligands other than, or in addition to, water, such as nitrates or carboxylates, coordinated to the three $\mathrm{UO}_{2}$ groups [51]. Complex c) is based on a structure [52] that contains the complex $\left[\left(\mathrm{UO}_{2}\right)_{4}(\mathrm{O})_{2}(\mathrm{OH})_{4}\left(\mathrm{H}_{2} \mathrm{O}\right)_{6}\right]$ as drawn $(\mathrm{CSD}$ code: TONSUL), except that two sites occupied by waters on the drawing are occupied by neutral carbonyl oxygen donors from complex organic molecules. Again, this is a motif, consisting of two oxide anions surrounded by four uranyl groups, that occurs in a variety of structures, including those where the bridging groups are chlorides [53] or thiocyanates [54] bridging through the $\mathrm{N}$ donor in place of the hydroxide bridges. 


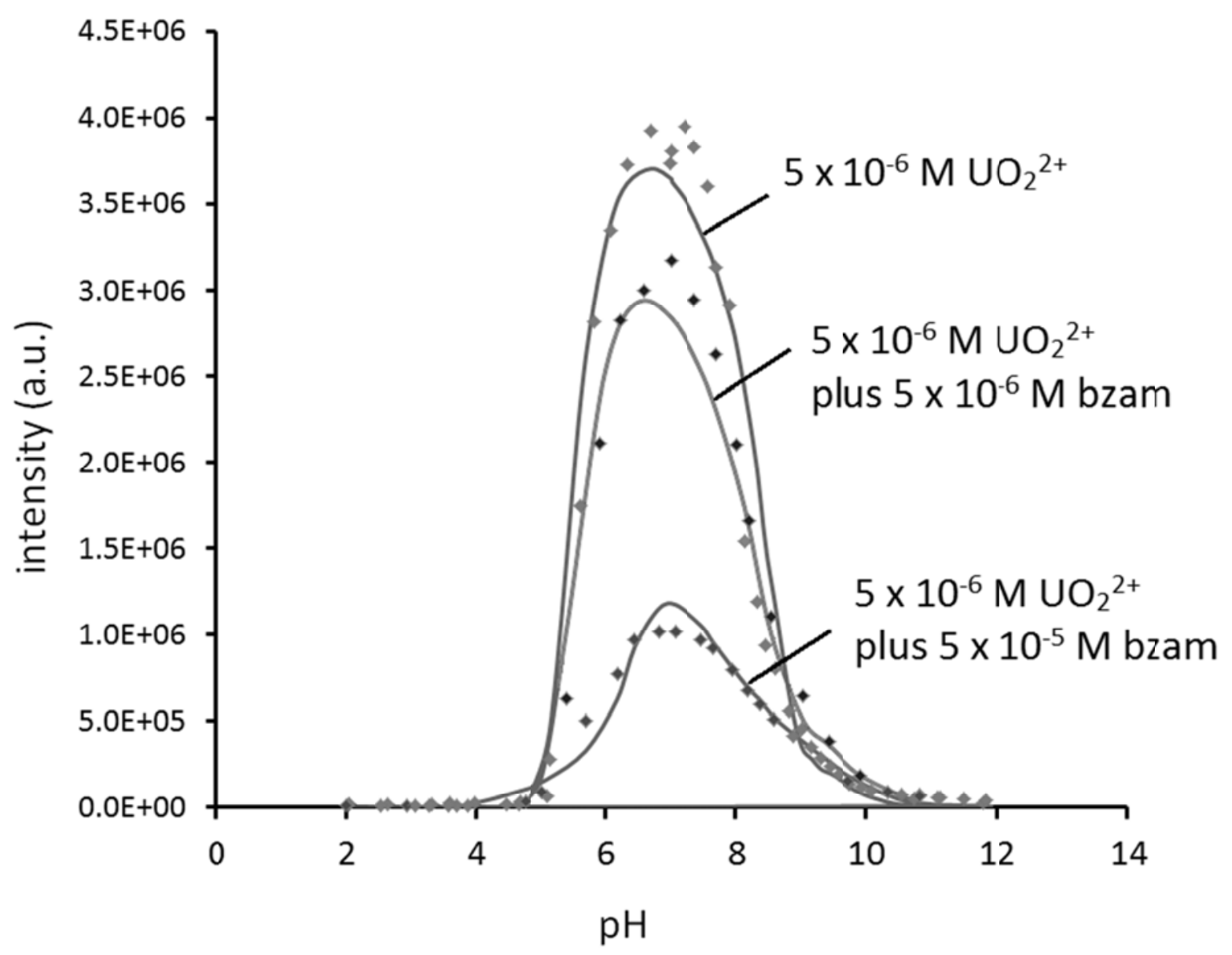

Figure 9. Variation of fluorescence intensity (solid points) at $514 \mathrm{~nm}$ of $5 \times 10^{-6} \mathrm{M} \mathrm{UO}_{2}{ }^{2+}$ solutions ( $\left(\right.$ s $\left.\mathrm{UO}_{2}\left(\mathrm{NO}_{3}\right)_{2}\right)$ as a function of $\mathrm{pH}$ : a) $\mathrm{UO}_{2}{ }^{2+}$ alone b) 1:1 bzam:uranyl, and c) 10:1 bzam:uranyl. The solid lines are the theoretical curves of fluorescence intensity vs $\mathrm{pH}$ calculated using the fluorescence intensities for the polymeric species calculated for the uranyl species alone in Figure 7, plus the concentrations of these species indicated by the program HYSS [22] in the presence of bzam complex-formation plus the formation constants given in Table 1. Wavelength of excitation $=290 \mathrm{~nm}$. 


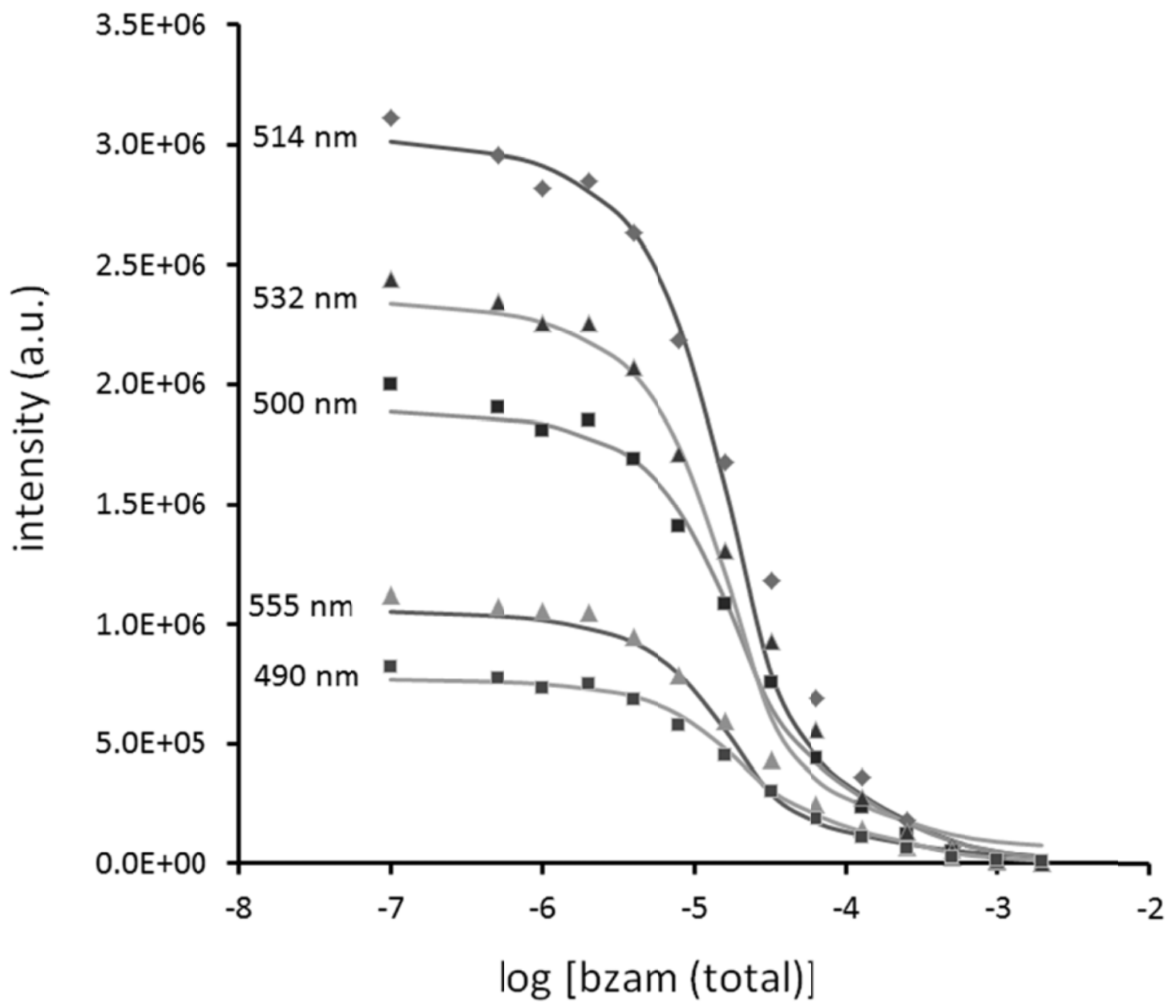

Figure 10. Fluorescence intensity at a selection of wavelengths of $5 \times 10^{-6} \mathrm{M} \mathrm{UO}_{2}\left(\mathrm{NO}_{3}\right)_{2}$ titrated at $\mathrm{pH} 7.66$ with $0.05 \mathrm{M}$ benzamidoxime. Solid points = experimental values, solid lines = theoretical curves fitted as described in the text. 


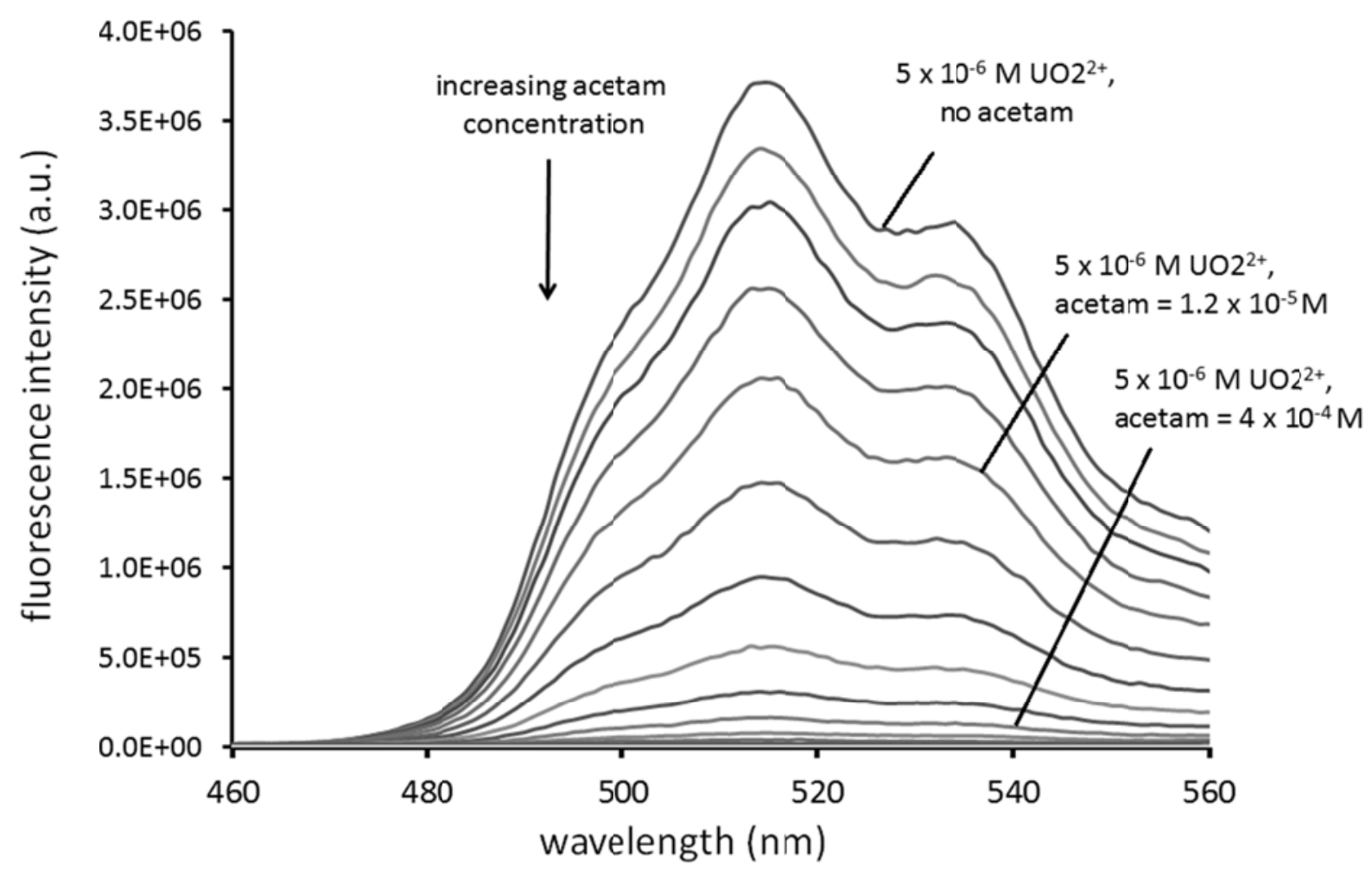

Figure 11. Titration of $5 \times 10^{-6} \mathrm{M} \mathrm{UO}_{2}\left(\mathrm{NO}_{3}\right)_{2}$ at a constant $\mathrm{pH}$ of 7.38 with $0.05 \mathrm{M}$ acetam. 


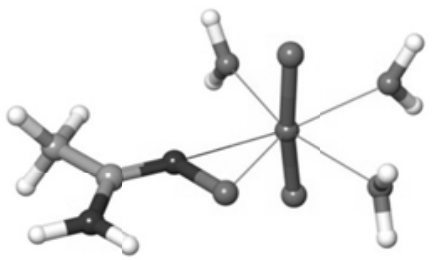

$\left[\mathrm{UO}_{2}(\text { acetam })\left(\mathrm{H}_{2} \mathrm{O}\right)_{3}\right]^{+}$

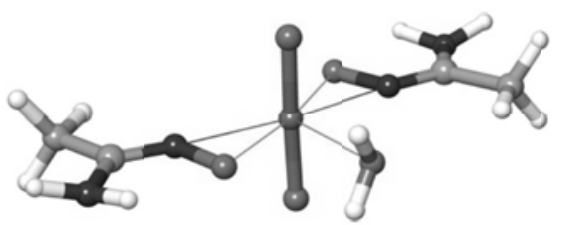

$\left[\mathrm{UO}_{2}(\text { acetam })_{2}\left(\mathrm{H}_{2} \mathrm{O}\right)\right]$

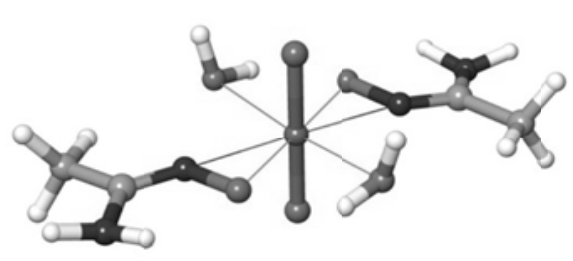

$\left[\mathrm{UO}_{2}(\operatorname{acetam})_{2}\left(\mathrm{H}_{2} \mathrm{O}\right)_{2}\right]$

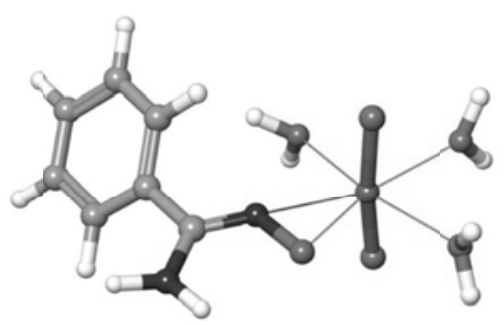

$\left[\mathrm{UO}_{2}(\text { bzam })\left(\mathrm{H}_{2} \mathrm{O}\right)_{3}\right]^{+}$

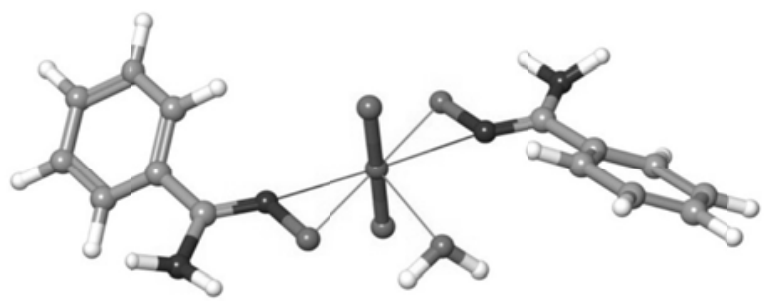

$\left[\mathrm{UO}_{2}(\text { bzam })_{2}\left(\mathrm{H}_{2} \mathrm{O}\right)\right]$

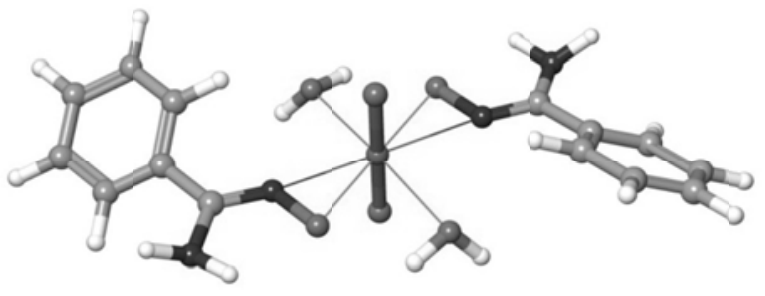

$\left[\mathrm{UO}_{2}(\text { bzam })_{2}\left(\mathrm{H}_{2} \mathrm{O}\right)_{2}\right]$

Figure 12. Structures of uranyl complexes with acetam and bzam obtained after geometry optimization at the M06/SSC/6-311++G(d,p) level of theory. 


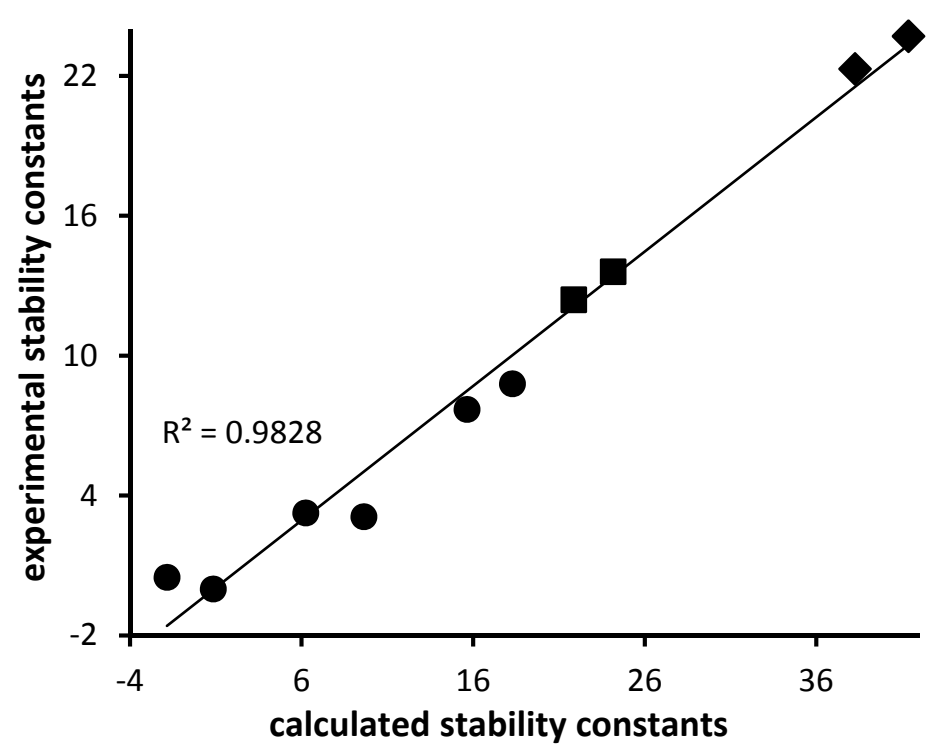

Figure 13. Plots of experimental versus calculated stability constants for uranyl complexes with monovalent negative donor ligands. The computed values were obtained at the M06/6-311++G(d,p) level of theory with solvent corrections obtained using the SMD solvation model. The calculated $\log \mathrm{K}_{1}$ values for monovalent negative oxygen donor ligands (•) and acetam (ם) were taken from ref [35]. The calculated $\log K_{1}$ values for bzam ( $\left.\square\right)$ and $\log \beta_{2}$ values for acetam and bzam $(\bullet)$ are obtained in the current work. 


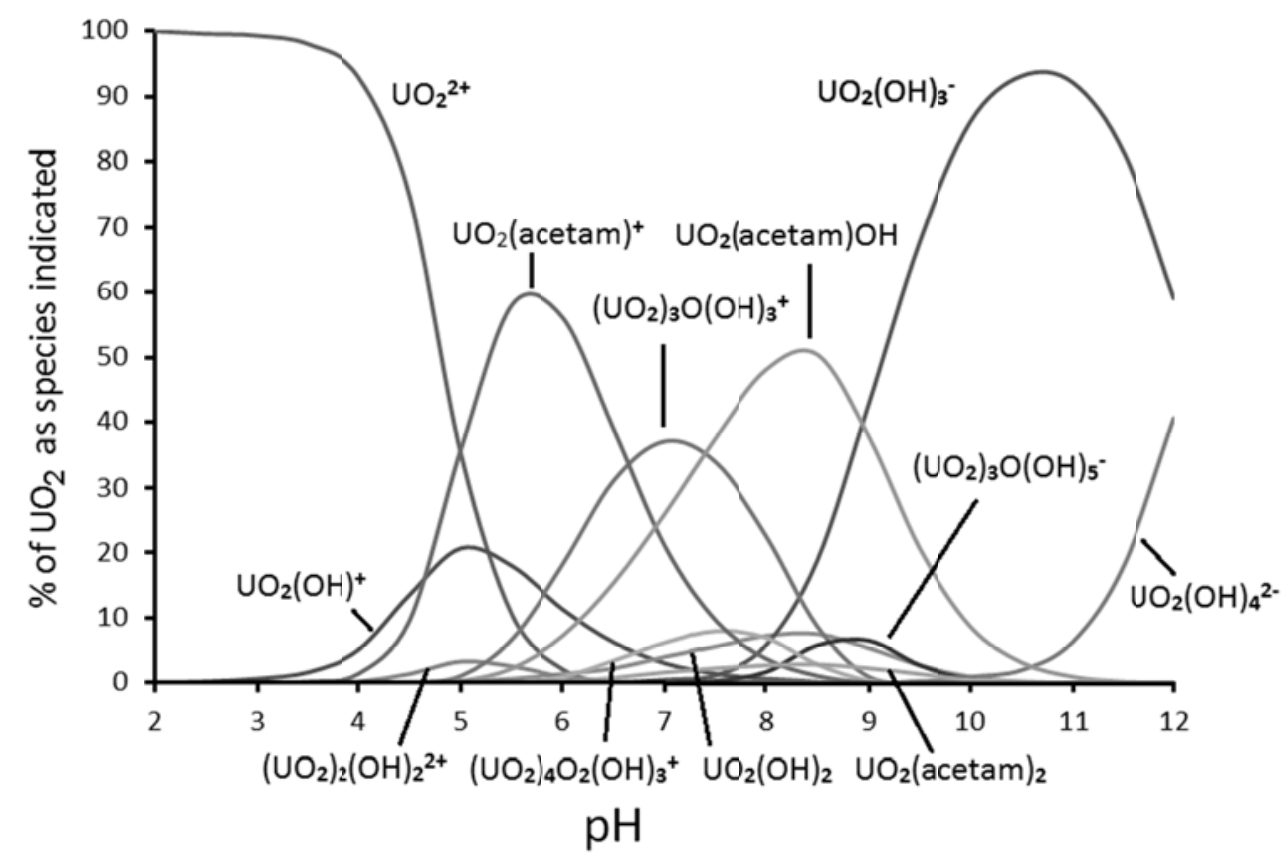

Figure 14. Species distribution diagram for $5 \times 10^{-6} \mathrm{M} \mathrm{UO}_{2}{ }^{2+}$ plus $1.48 \times 10^{-5} \mathrm{M}$ acetam as a function of $\mathrm{pH}$. Daiagram was calculated with HySS [22] using constants for uranyl hydroxo species from reference [18] and for the uranyl acetam species from this work. 


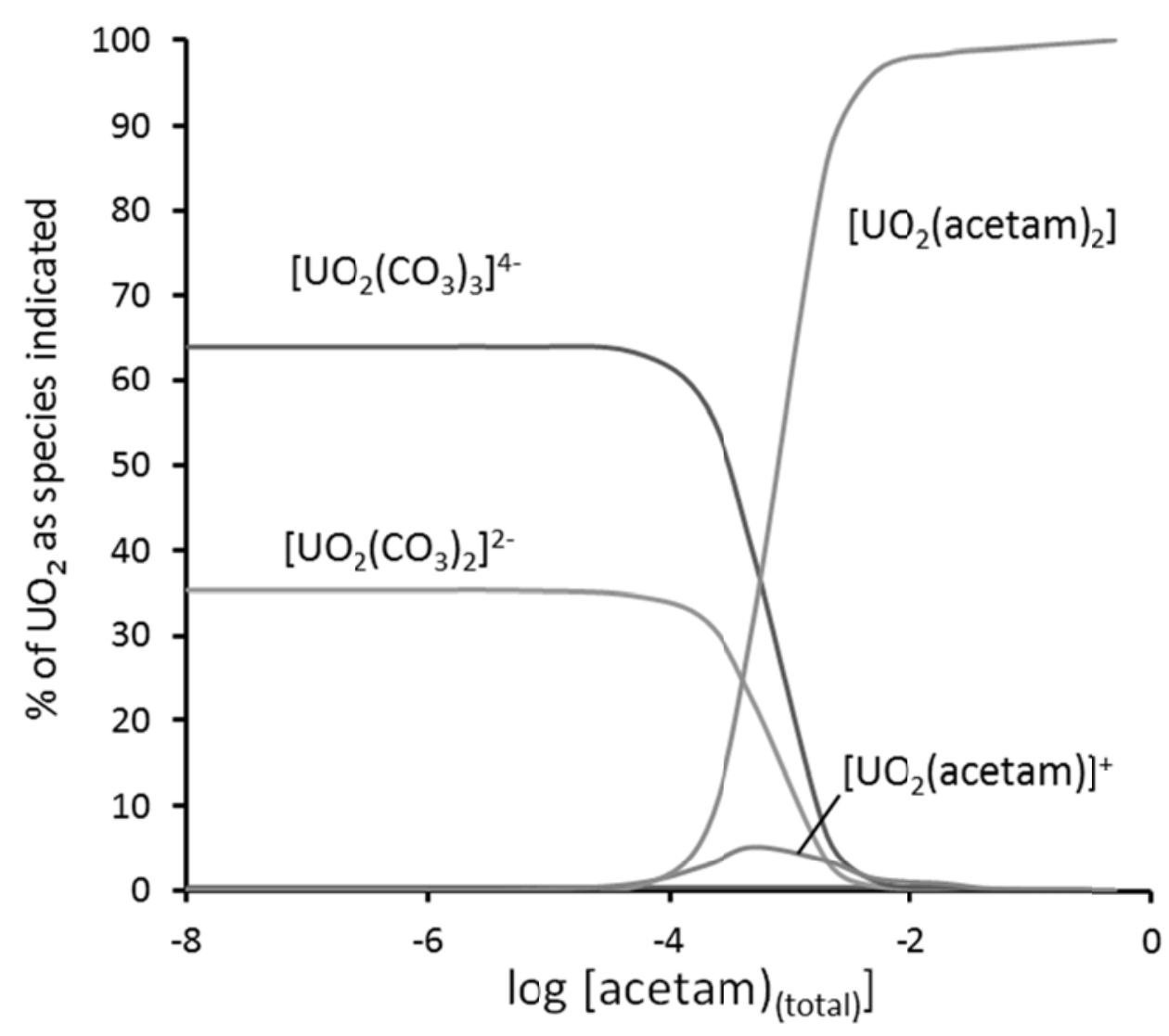

Figure 15. Species distribution diagram calculated using the program HySS [22]. for $1.3 \times 10^{-8}$ $\mathrm{M} \mathrm{UO}_{2}{ }^{2+}$ in $0.0025 \mathrm{M} \mathrm{Na}_{2} \mathrm{CO}_{3}$ (the concentrations of uranyl and $\mathrm{CO}_{3}{ }^{2-}$ in seawater [7]) as a function of acetam concentration at $\mathrm{pH} 8.5$ in aqueous solution at $25^{\circ} \mathrm{C}$. The diagram illustrates the total acetam concentration at which the carbonato complexes would be displaced by acetam complexes. It has been estimated that the concentration of acetamidoxime functional groups in the volume of water containing polymer strands bearing such functional groups would be about $0.1 \mathrm{M}$. This is in accord with the ability of such polymeric materials to extract uranyl cations from seawater as acetam complexes at $\log \left[(\text { acetam })_{\text {total }}\right]=-0.1$ on the diagram . The diagram was calculated with formation constants at ionic strength zero and $25^{\circ} \mathrm{C}$ for uranyl hydroxo and carbonato species $[18,64]$ and values determined here for the acetam complexes. 
Entry for graphical index:

\section{Amidoximes as Ligand Functionalities for Braided Polymeric Materials for the Recovery of Uranium from Seawater.}

Mark A. Lashley, Nada Mehio, Joseph W. Nugent, Erick Holguin, Sheng Dai, and Robert D. Hancock.

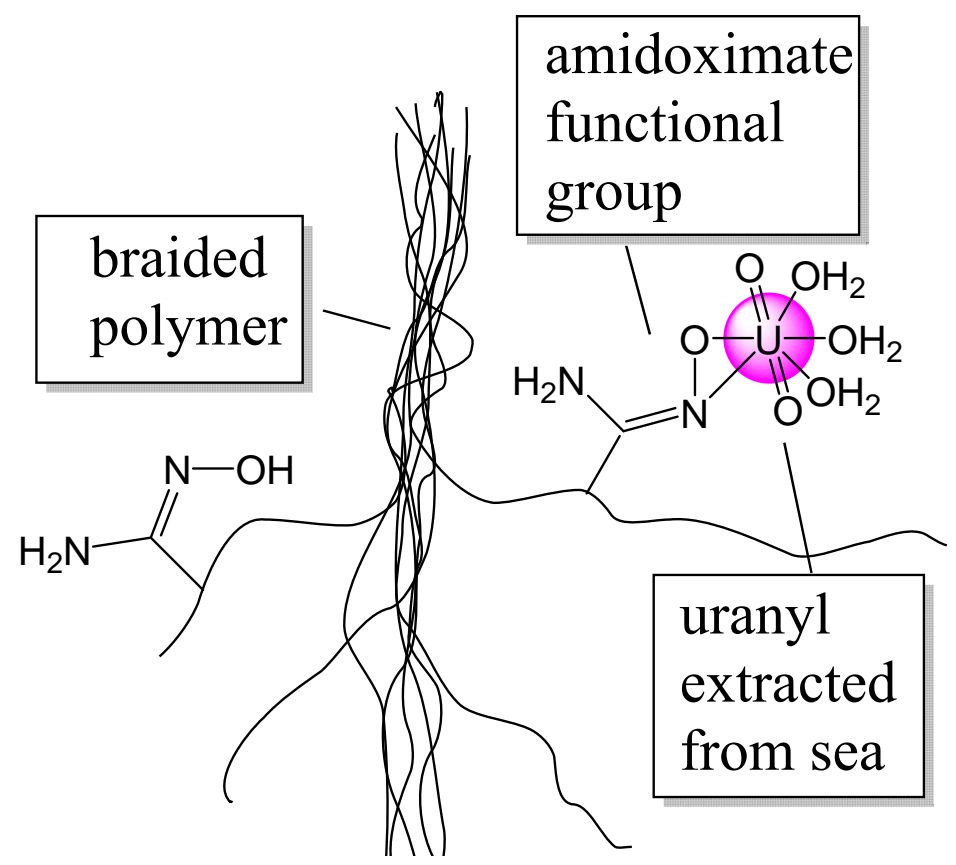

The formation constants of the amidoximate ligands bzam (benzamidoxime) and acetam (acetamidoxime) with the uranyl ion were measured by absorbance and fluorescence spectroscopy, which yield at $25^{\circ} \mathrm{C}$ and ionic strength $=0$, for bzam: $\log \mathrm{K}_{1}=12.4, \log \beta_{2}=22.3$, for acetam: $\log K_{1}=13.6, \log \beta_{2}=23.7$. These $\log \mathrm{K}$ values are related to the possible use of amidoximate groups as the functional groups attached to polymeric materials as the basis for recovering uranium from the oceans. 